\title{
Recent Trends in Energy Research and Development Expenditures
}

R. J. Moe, Project Manager

J. R. Kee

K. C. Lackey

F. J. Cronin

February 1985

Prepared for the U.S. Department of Energy under Contract DE-AC06-76RLO 1830

Pacific Northwest Laboratory Operated for the U.S. Department of Energy by Battelle Memorial Institute 


\title{
DISCLAIMER
}

This report was prepared as an account of work sponsored by an agency of the United States Government. Neither the United States Government nor any agency thereof, nor any of their employees, makes any warranty, express or implied, or assumes any legal liability or responsibility for the accuracy, completeness, or usefulness of any information, apparatus, product, or process disclosed, or represents that its use would not infringe privately owned rights. Reference herein to any specific commercial product, process, or service by trade name, trademark, manufacturer, or otherwise, does not necessarily constitute or imply its endorsement, recommendation, or favoring by the United States Government or any agency thereof. The views and opinions of authors expressed herein do not necessarily state or reflect those of the United States Government or any agency thereof.

\author{
PACIFIC NORTHWEST LABORATORY \\ operated by \\ BATTELLE \\ for the \\ UNITED STATES DEPARTMENT OF ENERGY \\ under Contract DE-AC06-76RLO 1830
}

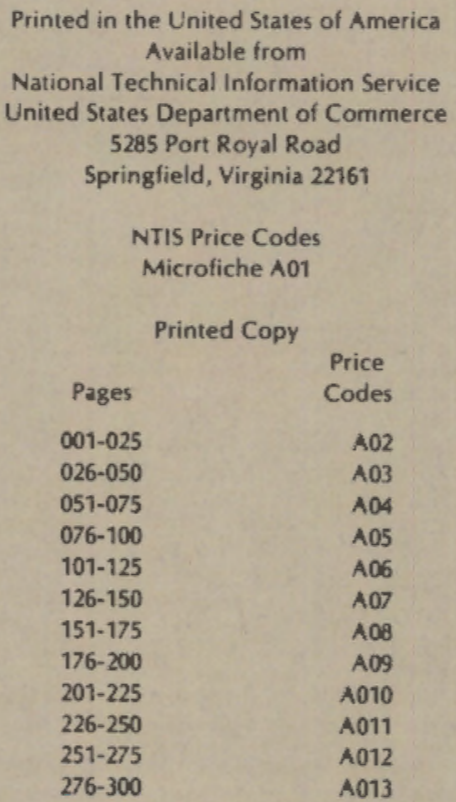


R. J. Moe, Project Manager

J. R. Kee

K. C. Lackey

F. J. Cronin

February 1985

Prepared for

the U.S. Department of Energy

under Contract DE-AC06-76RLO 1830

Pacific Northwest Laboratory Richland, Washington 99352 



\section{EXECUTIVE SUMMARY}

Pacific Northwest Laboratory (PNL) has prepared this report for the Department of Energy, Office of Industrial Programs (OIP). The objective of this report is to analyze recent trends in industrial research and development (R\&D) spending, using data provided by the National Science Foundation. The specific emphasis of the report is energy and energy conservation R\&D expenditures. Analyzing the causes of recent R\&D expenditure trends was outside of the scope of the study, as was collecting primary R\&D expenditure data from industrial firms.

This objective was achieved by performing two tasks. The first task was to collect and assemble data on industrial R\&D expenditures in the United States from the National Science Foundation (NSF), Office of Industrial Studies. The NSF data base contains information on R\&D expenditures by year for each of the years 1975-1982, by two- and three-digit Standard Industrial Code (SIC), and by R\&D type (total, energy, and energy conservation). The NSF defines R\&D as either basic investigatory research, without commercial objectives; applied research with commercial objectives; or technical activities concerned with creating or developing new products or processes. Energy R\&D is any R\&D activity concerned with investigating or developing new uses of energy. Energy conservation R\&D, a subset of energy R\&D, is any $R \& D$ activity concerned with investigating or developing new energy-saving products or processes.

The data cover the expenditures for R\&D performed by private industry, including R\&D that is both financed and performed by private industry and R\&D that is financed by the government (federal, state, and/or local) but performed by the private sector. The data do not cover expenditures for R\&D that was actually performed by the government (such as research performed by the National Institutes of Health or the National Bureau of Standards). Although the NSF has recently released this data to the public in a report entitled R\&D in Industry: 1982 Statistical Tables, to our knowledge the data has not yet been used to perform an analysis of the type reported in this paper. In addition to the information on R\&D expenditures, data on the Gross 
National Product (GNP) implicit price deflator for the years 1975-1982 was obtained from the 1984 Economic Report of the President

The second task was to graphically and numercially analyze recent trends in total, energy-related, and energy conservation R\&D expenditures. Total R\&D and energy R\&D expenditures for the period 1975-1982 were analyzed for each of nine industries: chemicals, petroleum, primary metals, machinery, electrical equipment, aircraft and missiles, professional and scientific instruments, other manufacturing, nonmanufacturing. Energy conservation R\&D expenditures for this period were analyzed for each of six industries: chemicals, primary metals, machinery, electrical equipment, other manufacturing, and nonmanufacturing. In addition, for all three types of $R \& D$, trends in expenditures for all industries combined were analyzed.

The findings of this task are summarized in Tables ES. 1 and ES.2 and Figures ES.1, ES.2, and ES.3. As shown in Table ES.1, between 1975 and 1982 , real (inflation-adjusted) total R\&D expenditures by a 11 industries combined increased at an annual average rate of 5.6 percent. Real energy-related R\&D expenditures by al1 industries increased at an annual average rate of 5.6 percent for the entire 1975-1982 period; however, they increased at an annua? average rate of 10.6 percent between 1975 and 1980 , and decreased at an annual average rate of 5.3 percent between 1980 and 1982 . Rea1 energy conservation expenditures by all industries increased at an annual average rate of 11.1 percent for the entire 1975-1982 period; however, they increased at an annual average rate of 49.8 percent between 1975 and 1979 , but decreased at an annual average rate of 25.2 percent between 1979 and 1982 .

Although energy $R \& D$ expenditures and tota? R\&D expenditures for al industries combined increased at identical annual rates during the 1975-1982 period, energy $R \& D$ expenditures increased at higher annual average rates than total R\&D expenditures in seven of the nine individual industries analyzed. Conservation R\&D expenditures increased at higher average annual rates than either energy or total R\&D expenditures in four of the five individual industries for which comparisons could be made. As might be expected, tota? $R \& 0$ increased at the highest average annual rate in the professionat and scientific instruments industry, which includes the electronics industry. Energy R\&D expenditures grew at the highest annual average rate in the 
TABLE ES.1. Annual Average Rates of Change in Rea T U.S. Research and Development Expenditures, by Industry and Type of R\&D, $1975-1982$

\begin{tabular}{|c|c|c|c|}
\hline & \multicolumn{2}{|c|}{ Type of R\&D } & \multirow[b]{2}{*}{$\begin{array}{c}\text { Energy } \\
\text { Conservation }\end{array}$} \\
\hline & Total & Energy & \\
\hline Chemicals & .054 & .085 & .185 \\
\hline Petroleum & .076 & .083 & $N A(a)$ \\
\hline Primary Metals & .045 & .122 & .204 \\
\hline Machinery & .058 & .267 & -.023 \\
\hline $\begin{array}{l}\text { Electrical } \\
\text { Equipment }\end{array}$ & .049 & .017 & .124 \\
\hline $\begin{array}{l}\text { Aircraft and } \\
\text { Missiles }\end{array}$ & .057 & .067 & $N A(a)$ \\
\hline $\begin{array}{l}\text { Professional and } \\
\text { Scientific } \\
\text { Instruments }\end{array}$ & .110 & .184 & $N A(a)$ \\
\hline $\begin{array}{l}\text { Other } \\
\text { Manufacturing(b) }\end{array}$ & .036 & -.002 & .074 \\
\hline Nonmanufacturing & .085 & .127 & .260 \\
\hline Total Industry & .056 & .056 & .111 \\
\hline
\end{tabular}

(a) Not available, included in "Other Manufacturing" category.

(b) The Energy Conservation average annual rate of change should not be compared to the Total and Energy rates for this industry because the industry is defined differentiy for the Energy Conservation column than for the Total and Energy columns.

machinery industry. Energy conservation R\&D expenditures increased at the highest annual average rate in the nonmanufacturing (primarily commercial) and primary metals industries.

The real average annual rates of increase presented in Table ES. 1 may be somewhat misleading, for two reasons. First, although real energy and energy conservation R\&D expenditures increased in most of the individual industries at higher annual average rates than real total R\&D expenditures, the actual real dollar increases that occurred between 1975 and 1982 were much Targer for total R\&D than for efther energy or energy conservation R\&D. For example, as shown in Table ES.2, real total industrial R\&D 
TA8LE ES.2. Real U.S. Research and Development Expenditures, by Industry and Type of R\&D, 1975, Peak Year. and 1982

$$
\text { (Millions of } 1972 \text { Dollars) }
$$

\section{Type of R\&D}

\begin{tabular}{|c|c|c|c|c|c|c|c|c|}
\hline & \multicolumn{2}{|c|}{ Total } & \multicolumn{3}{|c|}{ Energy } & \multicolumn{3}{|c|}{$\begin{array}{c}\text { Energy } \\
\text { Conservation }\end{array}$} \\
\hline & 1975 & $1982(a)$ & 1975 & Peak & 1982 & 1975 & Peak & 1982 \\
\hline Chemicals & 2164 & 3137 & 81 & (d) & 165 & 3 & 27 & 11 \\
\hline Petroleum & 550 & 921 & 321 & (d) & 563 & $N A(b)$ & NA $(b)$ & NA(b) \\
\hline Primary Metals & 352 & 479 & 21 & (d) & 48 & 2 & 14 & 8 \\
\hline Machinery & 2537 & 3751 & 18 & (d) & 92 & 1 & 8 & 1 \\
\hline $\begin{array}{l}\text { Electrical } \\
\text { Equipment }\end{array}$ & 4052 & 5678 & 368 & 517 & 416 & 6 & 30 & 14 \\
\hline $\begin{array}{l}\text { Aircraft and } \\
\text { Missiles }\end{array}$ & 4534 & 6688 & 106 & 251 & 168 & $N A(b)$ & $N A(b)$ & $\mathrm{NA}(\mathrm{b})$ \\
\hline Professional & 931 & 1927 & 11 & (d) & 36 & NAb & NAb & $N A^{b}$ \\
\hline $\begin{array}{l}\text { Other } \\
\text { Manufacturing (c) }\end{array}$ & 3499 & 4521 & 403 & 566 & 407 & 26 & 121 & 44 \\
\hline Nonmanufacturing & 584 & 1046 & 78 & 198 & 182 & 1 & 11 & 8 \\
\hline Total Industry & 19228 & 28451 & 1410 & 2330 & 2091 & 41 & 207 & 87 \\
\hline
\end{tabular}

(a) For tota1 R\&D expenditures, 1982 was the peak year for each of the nine industries. so a separate "Peak Year" column is not shown.

(b) Not available, included in "Other Manufacturing" category.

(c) This industry is defined differently for the Energy Conservation columns than for the Total and Energy Columns.

(d) Peak year was 1982 . 


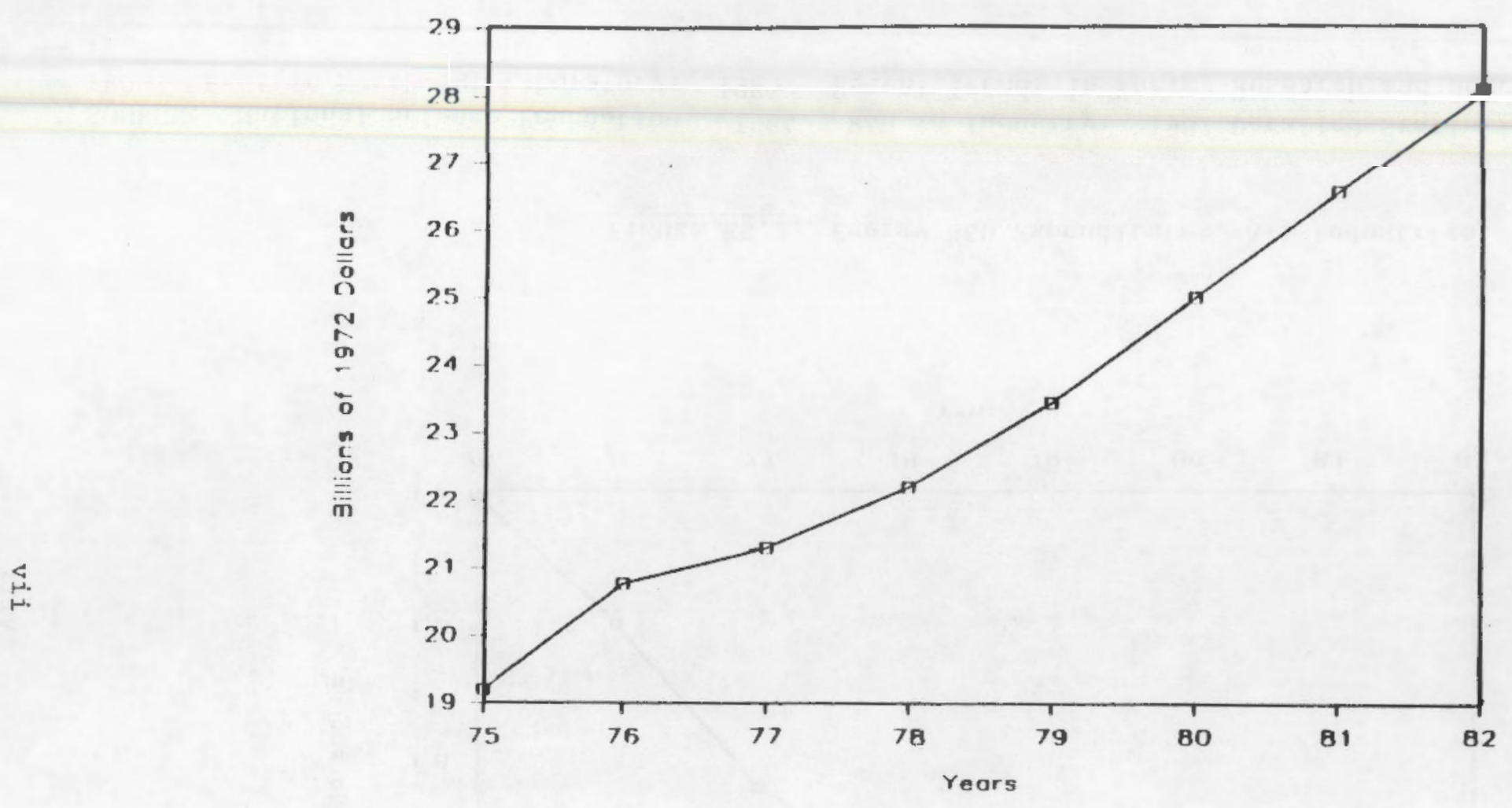

FIGURE ES.1. Tota1 R\&D Expenditures, A11 Industries.

SOURCE: National Science Foundation. 1984. R\&D In Industry: 1982 Detalled Statistical Tables.

FROM: Pacific Northwest Laboratory. 1985. Recent Trends In Energy Research and Development Expenditures. 


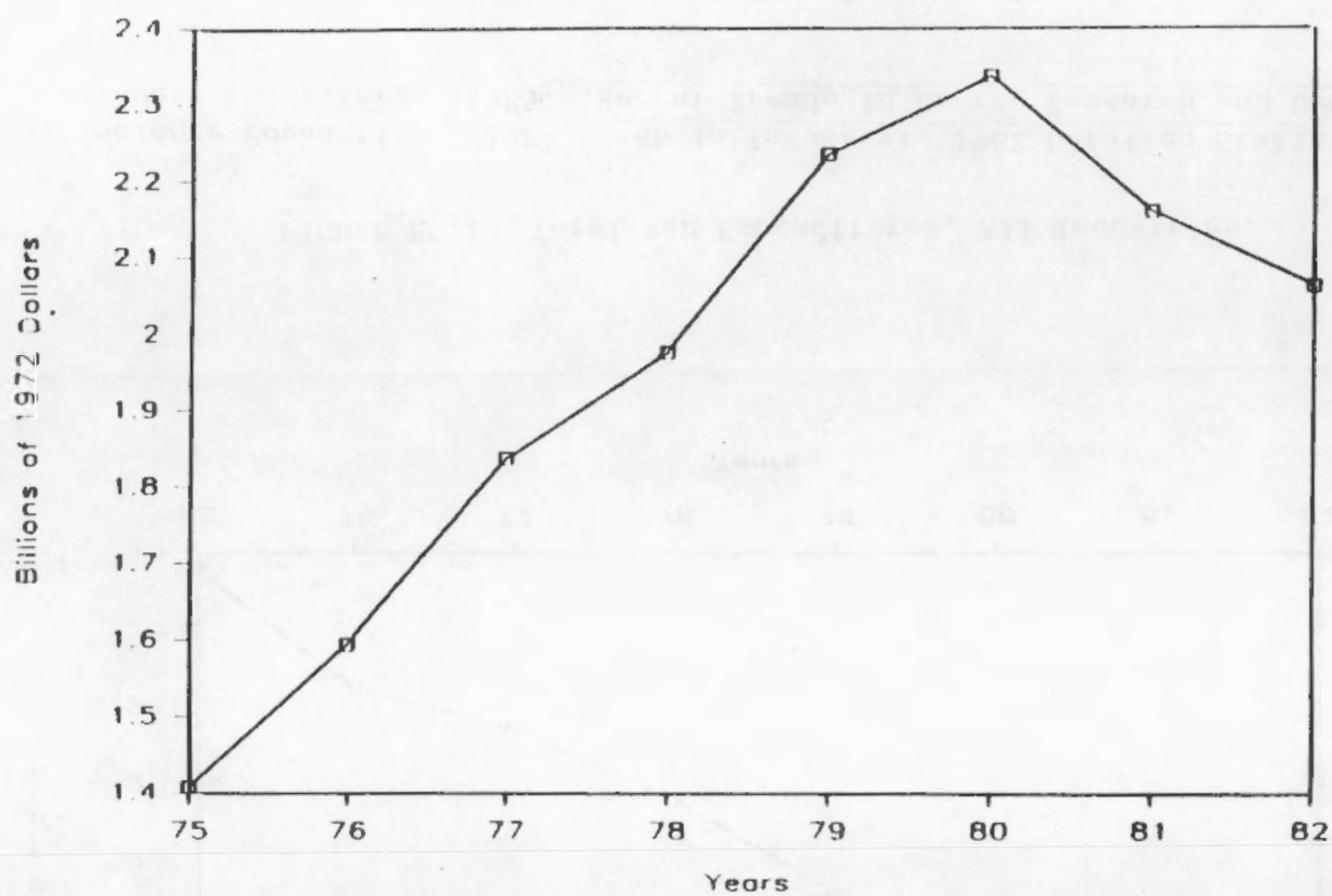

FIGURE ES.2. Energy R\&D Expenditures, All Industries.

SOURCE: National Science Foundation. 1984. R\&D In Industry: 1982 Detalled Statlet Ical Tables. FROM: Pacific Northwest Laboratory. 1985. Recent Trends In Energy Research and Development Expenditures. 


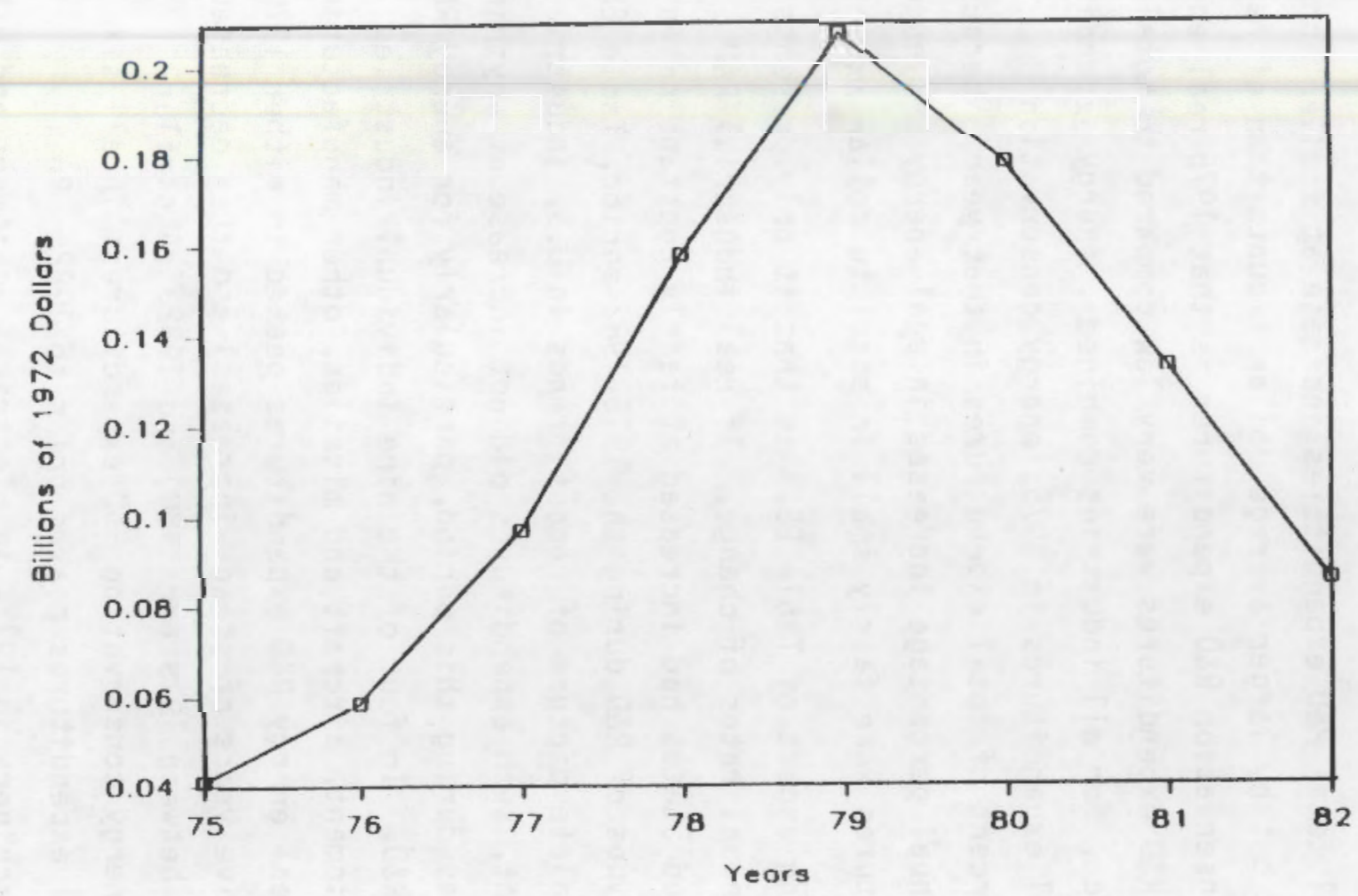

FIGURE ES. 3. Energy Conservation R\&D Expenditures, All Industries.

SOURCE: National Science Foundation. 1984. R\&D in Industry: 1982 Detailed Statistical Tables.

FROM: Pacific Northwest Laboratory. 1985. Recent Trends in Energy Research and Development Expenditures. 
expenditures for a 11 industries combined increased from $\$ 19,228$ million in 1975 to $\$ 28,451$ million in 1982 , an average increase of $\$ 1,318$ million per year. Real energy R\&D expenditures increased by all industries an average of $\$ 97$ million per year between 1975 and 1982. Real energy conservation R\&D expenditures by all industries increased an average of $\$ 7$ million per year between 1975 and 1982. Similar examples could be drawn from most of the individual industries analyzed.

The reason that real total R\&D expenditures increase at smaller annual average percentage rates but by larger average dollar amounts than either real energy or energy conservation R\&D expenditures is that 1975 real energy and energy conservation R\&D expenditures were very low compared to total $R \& D$ expenditures. In fact, for alt industries combined, energy expenditures were 7.3 percent of total expenditures in 1975; energy conservation expenditures were 0.2 percent of total expenditures in that year. Because of this, fairly large annual percentage increases in real energy and energy conservation R\&D expenditures were fairly small in absolute dollar amounts.

The second misleading aspect of Table ES. 1 is that it only presents information on average annual rates of change. If real industrial R\&D expenditures in the United States had increased at fairly constant rates for all industries and all types of R\&D during the 1975-1982 period, Table ES. 1 would paint a fairly complete picture of recent trends in U.S. industrial $R \& D$ expenditures. In fact, such expenditures did not increase at anything approaching constant rates during this period, particularly for energy R\&D and energy conservation R\&D. In four of the nine individual industries analyzed (electrical equipment, aircraft and missiles, other manufacturing. and nonmanufacturing), real energy R\&D expenditures peaked in either 1979 or 1980 (after four or five years of steady increases) and then decreased at fairly constant rates between 1979 (or 1980) and 1982. A similar phenomenon occurred in energy conservation R\&D expenditures: in all six industries analyzed, real expenditures peaked prior to 1982 . Real expenditures peaked in machinery in 1977, in electrical equipment and other manufacturing in 1979, and in primary metals and nonmanufacturing in 1980 . In all six industries, real energy conservation R\&D expenditures increased at fairly constant (and very high) rates between 1975 and the peak year, 
but then decreased at fairly constant (and, again, very high, though not quite as high as the previous rates of increase) rates between the peak year and 1982. Regarding total R\&D expenditures, in only one of the nine industries analyzed (other manufacturing) did real expenditures peak prior to 1982 .

This phenomenon is shown graphicaity in Figures ES.?. ES.2, and ES.3. which display the annual R\&D expenditures in billions of 1972 dollars for each of the three types of R\&D for all industries combined. Note that the vertical axes of these figures are scaled differently, reflecting the fact that energy R\&D expenditures are a very sma 11 share of total R\&D expenditures and that energy conservation R\&D expenditures are a very small proportion of energy R\&D expenditures. Real total R\&D expenditures by all industries increased at a near-constant rate between 1975 and 1982, as shown in Figure ES.1. Real energy expenditures by all industries increased at near-constant rates between 1975 and 1980, but decreased in both 1981 and 1982, as displayed in Figure ES.2. As Figure ES. 3 shows, real energy conservation R\&D expenditures by all industries increased at near-constant (and very high) rates between 1975 and 1979, but decreased almost as dramatically between 1979 and 1982. For a 11 three categories of R\&D, real expenditures by individual industries exhibited similar tendencies. 
.

. 


\section{CONTENTS}

EXECUTIVE SUMMARY.$\quad \cdot \quad \cdot \quad \cdot \quad \cdot \quad \cdot \quad \cdot \quad \cdot \quad \cdot \quad \cdot$.

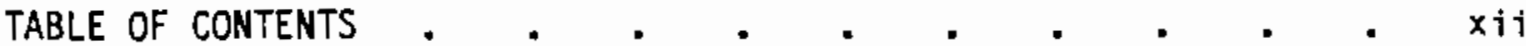

LIST OF FIGURES.



1.1 BACKGROUND. $\quad . \quad . \quad . \quad . \quad . \quad . \quad . \quad . \quad+1.1$

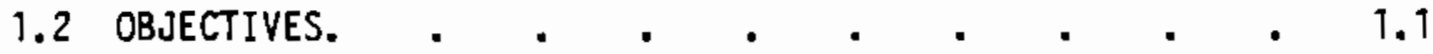

1.3 OVERVIEW OF REPORT . . . . . . . . . . . 1.2

2.0 CONCLUSIONS AND RECOMMENDATIONS $\quad \cdot \quad \cdot \quad .1$

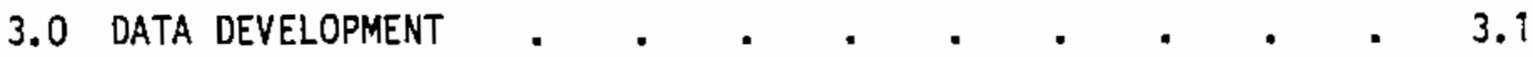

3.1 DATA SOURCES . . . . . . . . . . . 3.1

3.2 DATA DESCRIPTION . . . . . . . . . . . 3.1

3.2.1 Description of R\&D Expenditure Data . . . 3.?

3.2.2 Description of Price Deftator . . . . . 3.3

4.0 ANALYSIS OF R\&D EXPENDITURE TRENDS . . . . . . . . . . 4.1

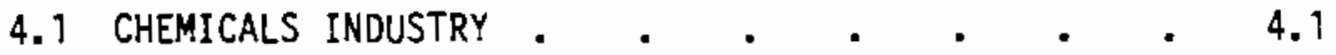

4.2 PETROLEUM INDUSTRY . . . . . . . . . 4.7

4.3 PRIMARY METALS INDUSTRY . . . . . . . 4.7

4.4 MACHINERY INDUSTRY . . . . . . * . . 4.16

4.5 ELECTRICAL EQUIPMENT INDUSTRY . • • • • • 4.16

4.6 AIRCRAFT AND MISSILES INDUSTRY..$\quad \cdot \quad \cdot \quad \cdot 4.25$

4.7 PROFESSIONAL AND SCIENTIFIC INSTRUMENTS INDUSTRY • 4.25

4.8 OTHER MANUFACTURING INDUSTRIES. $\quad \cdot \quad \cdot \quad \cdot \quad \cdot 33$

4.9 NONMANUFACTURING INDUSTRIES . . . . . . . 4.33

4.10 ALL INDUSTRIES. . . . . . . . 4.43

APPENDIX . . . . . . . . . . . . . . A.1 


\section{FIGURES}

4.1 (a) Total R\&D Expenditures, Chemicals Industry . . . . 4.2

4.1 (b) Energy R\&D Expenditures, Chemtcals Industry . . . . 4.3

4.1 (c) Energy Conservation R\&D Expenditures, Chemicals Industry . . 4.4

4.1 (d) Energy R\&D Expenditures as a percentage of total R\&D Expenditures, Chemical Industry . . . . . . . 4.5

4. 1 (e) Energy Conservation R\&D Expenditures as a Percentage of Total R\&D Expenditures, Chemical Industry . . . . 4.6

4.2 (a) Total R\&D Expenditures, Petroieum Industry . . . . . 4.8

4.2 (b) Energy R\&D Expenditures, Petroiuem Industry . . . . . . 4.9

4.2 (c) Energy R\&D Expenditures as a Percentage of Total R\&D Expenditures, Petroleum Industry . . . . . . 4.10

4.3 (a) Total R\&D Expenditures, Petroleum Industry, . . . . . 4.11

4.3 (b) Energy R\&D Expenditures, Primary Metals Industry . * . . 4.12

4.3 (c) Energy Conservation R\&D Expenditures, Primary Metals Industry . 4.13

4.3 (d) Energy R\&D Expenditures as a Percentage of Total R\&D Expenditures, Primary Metals Industry . . . . . 4.14

4.3 (e) Energy Conservation R\&D Expenditures as a Percentage of

4.4 (a) Total R\&D Expenditures, Machinery Industry . . . . 4.17

4.4 (b) Energy R\&D Expenditures, Machinery Industry . . . . . 4.18

4.4 (c) Energy Conservation R\&D Expenditures, Machinery Industry . . 4.19

4.4 (d) Energy R\&D Expenditures as a Percentage of Tota] R\&D Expenditures, Machinery Industry . . . . . . 4.20

4.4 (e) Energy Conservation R\&D Expenditures as a Percentage of Total R\&D Expenditures, Machinery Industry . . . . 4.21

4.5 (a) Total R\&D Expenditures, Electrical Equipment Industry . . 4.22

4.5 (b) Energy R\&D Expenditures, Electrical Equipment Industry . . 4.23

4.5 (c) Energy Conservation R\&D Expenditures, Electrical Equipment Industry $\quad$. . . . . . . . . 4.24

4.5 (d) Energy R\&D Expenditures as a Percentage of Tota1 R\&D Expenditures, ElectricaT Equipment Industry. . . . 4.26

4.5 (e) Energy Conservation R\&D Expenditures as a Percentage of Tota 1 R\&D Expenditures, Electrical Equipment Industry . . 4.27

4.6 (a) Total R\&D Expenditures, Aircraft and MissiTes Industry . 4.28

4.6 (b) Energy R\&D Expenditures, Aircraft and Missiles Industry . 4.29

4.6 (c) Energy R\&D Expenditures as a Percentage of Total R\&D Expenditures. Aircraft and Missiles Industry . . . 4.30 


\section{FIGURES (cont.)}

4.7 (a) Total R\&D Expenditures, Professtonal and Scientific Instruments Industry $\quad \cdot \quad \cdot \quad \cdot \quad \cdot \quad \cdot \quad \cdot \quad \cdot 31$

4.7 (b) Energy R\&D Expenditures, Professional and Scientific Instruments Industry $\cdot \quad \cdot \quad \cdot \quad \cdot \quad \cdot \quad \cdot \quad \cdot \quad \cdot \quad \cdot 4.32$

4.7 (c) Energy R\&D Expenditures as a Percentage of Total R\&D Expenditures, Professional and Sctentiftc Instruments Industry. $\quad 4.34$

4.8 (a) Total R\&D Expenditures, Other Manufacturing Industries . . 4.35

4.8 (b) Energy R\&D Expenditures, Other Manufacturing Industries • . 4.36

4.8 (c) Energy Conservation R\&D Expenditures, Other Manufacturing Industries . $. . \quad . \quad . \quad . \quad . \quad . \quad 4.37$

4.8 (d) Energy R\&D Expenditures as percentage of Total R\&D Expenditures, Other Manufacturing Industries . . . . 4.38

4.8 (e) Energy Conservation R\&D Expenditures as a Percentage of Tota1 R\&D Expenditures, Other Manufacturing Industries. . $\quad 4.39$

4.9 (a) Total R\&D Expenditures, Nonmanufacturing Industries . . . 4.40

4.9 (b) Energy R\&D Expenditures, Nonmanufacturing Industries. . 4.41

4.9 (c) Energy Conservation R\&D Expenditures, Nonmanufacturing

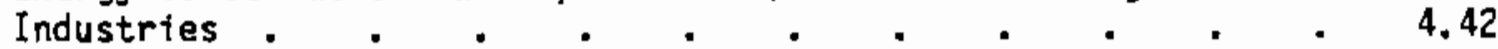

4.9 (d) Energy R\&D Expenditures as a Percentage of Tota 1 R\&D Expenditures, Nonmanufacturing Industries . . . . . . 4.44

4.9 (e) Energy Conservation R\&D Expenditures as a Percentage of Tota 1 R\&D Expenditures, Nonmanufacturing Industries. . 4.45

4.10 (a) Total R\&D Expenditures, All Industries . . . . . . . 4.46

4.10 (b) Energy R\&D Expenditures, ATl Industries . . . . . . 4.47

4. 10 (c) Energy Conservation R\&D Expenditures, A11 Industries . . 4.48

4.10 (d) Energy R\&D Expenditures as a Percentage of Total R\&D Expenditures, AT1 Industries . . . . . . 4.49

4.10 (e) Energy Conservation R\&D Expenditures as a Percentage
of Total R\&D Expend itures, All Industries. $. . \quad . \quad 4.50$ 
' 


\subsection{INTRODUCTION}

This report was prepared by Pacific Northwest Laboratory for the U.S. Department Energy, Office of Industrial Programs (OIP). The study analyzes recent trends in industrial expenditures on research and development (R\&D) of energy-using and energy-saving devices and methods.

\subsection{BACKGROUND}

Due to the relatively small productivity increases and the slowdown in real R\&D spending growth experienced during the 1970s, concern about industrial R\&D activity has dramatically increased in recent years. Output per man hour increased 32.2 percent between 1960 and 1970, but increased only 14.6 percent between 1970 and 1980, and actually fell in 1979 and 1980. Similarly, although real R\&D spending increased 23 percent between 1973 and 1981, this rate of increase was less than half the growth rate of 51 percent experienced in real R\&D spending during the 1963-1971 period. Such a reduction in the rate of growth of $R \& D$ investment may reduce long-term technological progress, and, in turn, endanger future productivity increases. In turn, a slowdown in technological progress may, over time, diminish our potentiai for continued economic strength.

Much less attention has been paid to recent trends in energy-related R\&D expenditures and the impact of such expenditures. Research and development expenditures relating to energy affect the U.S. economy by enhancing energy efficiency as well as the productivity of labor and equipment. An increase in energy-related R\&D expenditures and the resulting technological improvements facilitate the development of energy-saving devices and methods. These tools and capabilities enable industries to make better use of the energy they consume and reduce the amount of energy actually required. In addition, such R\&D expenditures lead to development of devices and methods that generaliy increase industrial productivity and that lead to new consumer and industrial products.

\subsection{OBJECTIVE}

The objective of this report is to summarize recent trends in industria? energy-related R\&D activity using data provided by the National Science 
Foundation. Analyzing the causes of these trends was outside of the scope of this study, as was collecting primary R\&D expenditure data from industriai firms. The results of this report are intended to provide DOE/OIP with information about recent energy $R \& D$ expenditures trends that it can use to identify problems in industrial activities.

\subsection{OVERVIEW OF REPORT}

The remainder of this report is organized as follows. Chapter 2.0 presents conclusions and recommendations of the study. Chapter 3.0 presents the data used in the analysis. Chapter 4.0 presents a quantitative assessment of total, energy, and conservation R\&D expenditure trends. 


\subsection{CONCLUSIONS AND RECOMMENDATIONS}

In brief, the study yielded the following conclusions:

- While total R\&D expenditures for all industries combined increased during every year in this period, energy and energy conservation R\&D expenditures for all industries combined peaked in 1980 and 1979 , respectively, and have been declining at constant rates since.

- Total, energy and energy conservation R\&D expenditures for all industries combined were higher in 1982 than in 1975, so that annual average rates of change were positive for all three categories for the period. This phenomenon occured in almost all of the industries anatyzed.

- Real energy and energy conservation R\&D expenditures began the 1975-1982 period as small proportions of total real R\&D spending ( 7.3 percent and 0.2 percent, respectively, for all industries combined in 1975) and generally ended the period as small proportions of total spending ( 7.3 percent and 0.3 percent respectively, for all industries combined in 1982). This phenomena occured in most of the industries analyzed.

Based upon these conclusions, the following recommendations are made:

- Real energy R\&D expenditures and, particulariy, real energy conservation R\&D expenditures have been decreasing during the past several years and appear likely to continue to decrease in the absence of policy intervention. To the extent that future industrial productivity increases, industrial strength, and "energy independence" are dependent on such expenditures (which we did not examine), policies to reverse the declines in these expenditures may be warranted.

- Further research should be performed on the recent trends in industrial $R \& D$ expenditures. Longer time series and more disaggregated expenditure data (e.g., by 4-digit SIC, by financing source, by type of R\&D) would be useful in determining how strong recent trends have been and the likelihood that they will continue. Research on the causes of the recent trends in $R \& D$ expenditures and on the effects of $R \& D$ expenditures 
on industrial productivity and industrial energy use should also be performed. 


\subsection{DATA DEVELOPMENT}

This chapter describes the data used in the trends analys is presented in chapter 4.0. The sources of this data are discussed in section 3.1. The data are described in detail in section 3.2 .

\subsection{DATA SOURCES}

Two general types of data were used in the analys is presented in chapter 4.0. First, data on annual industrial R\&D expenditures by industry and R\&D type were used. Second, the annual U.S. Gross National Product (GNP) implicit price deflator was used.

All industrial R\&O expenditures data were obtained from the National Science Foundation survey, R\&D in Industry: 1982 Oetailed Statistical Tables. (a) The data from this survey are collected and compiled by the Bureau of the Census, U.S. Department of Commerce.

Data on GNP implicit price deflator were obtained from the 1984 Economic Report of the President, pubTished by the Council of Economic Advisers, Executive Office of the President.(b) These data are collected by the Bureau of Economic Analysis, U.S. Department of Commerce.

\subsection{OATA DESCRIPTION}

The two types of data used in the analysis are described in greater detail below.

\subsubsection{Description of R\&D Expenditure Data}

The NSF survey of industrial R\&D consists of annual R\&D expenditure data for each of the years 1972 to 1982. The industrial R\&D data is organized according to Standard Industrial Classification (SIC) codes for 15 manufacturing industries: Food and Kindred Products; Textiles and Apparel; Lumber; Wood Products and Furniture; Petroleum Refining and Related Industries; Rubber Products; Stone, Clay and Glass Products; Primary Metals;

(a) National Science Foundation. 1984. R\&D in Industry: 1982 Statistical Tables. NSF84-325. Washington, D. C.

(b) Council of Economic Advisers. 1984. Economic Report of the Presidert. United States Government Printing Office, Washington, D. C. 
Fabricated Metal Products; Machinery; Motor Vehicles and Motor Vehicles Equipment; Other Transportation Equipment; Aircraft and Missiles; Professional and Scientific Instruments; and Other Manufacturing. Data for nonmanufacturing industries and a total for all indutries is also provided.

For several industry groupings, the NSF reported data as unavailable. This occurred when there was: 1) an extremely high sampling error; 2) a high rate of interpolation (over 50 percent); 3) a failure of a company to supply data; 4) disclosure of an individual company; and/or 5) inconsistency for inclusion in time series. Because of these suppressions, and in order to ensure a high degree of accuracy in analyzing $R \& D$ expenditure trends, total and energy R\&D expenditures for the period 1975-1982 were aggregated in this study into nine industrial categories: Chemical and Ali ied Products; Petroleum Refinery and Related Industries; Primary Metals; Machinery; Electrical Equipment; Aircraft and Missiles; Professional and Scientific Instruments; Other Manufacturing; and Nonmanufacturing, in addition to a total for all industries. The "Other Manufacturing Industry" used here is a composite of NSF's "Other Manufacturing Industry"; Food and Kindred Products; Textiles and Apparel; Lumber; Wood Products and Furniture; Rubber Products; Stone, Clay, and Glass Products; Fabricated Metal Products; Motor Vehicles; and Other Transportation Equipment. For the energy conservation expenditures, expenditure data were aggregated into six industries categories: Chemical and Allied Products; Primary Metals; Machinery; Electrical Equipment; Other Manufacturing; and Nonmanufacturing, in addition to a total for all industries. The "Other Manufacturing Industry" here inciudes the industries that made up "Other Manufacturing" for total and energy R\&D expenditures, plus the Petroleum Refining and Related Industries, Aircraft and Missiles, and Professional and Scientific Instruments.

The NSF reports data by R\&D type, for three types of R\&D: total, energy, and energy conservation. Total R\&D is defined as the total of all expenditures on R\&D activities for a given year. R\&D is defined by NSF as basic and applied research in sciences and engineering and the design and development of prototypes and processes. Research is differentiated as basic and applied research on the basis of original investigation. 
Basic research means an original investigation, one that has no commercial objective; otherwise the research is classified as applied. Development is defined by NSF as nonroutine technical activities concerned with creating products or processes from research findings.

Energy $R \& D$ is defined by the Organization for Economic Cooperation and Development (OECD) as R\&D performed "in support of the supply, production, and conservation and distribution of all forms of energy (except means of propulsion for vehicles and rockets)". The NSF uses this definition as well.

Energy conservation is defined by the NSF as R\&D undertaken to reduce consumption of energy, either at the point of energy use or in the transmission, transportation, storage, or coversion of energy. Examples are R\&D undertaken primarily to reduce fuel consumption in manufacturing, to improve the efficiency of transformation of energy products, and to produce an end product that is more efficient in energy utilization.

The data include expenditures for a17 R\&D activities performed by private industry. The source of financing of the activity is not considered: both R\&D activity financed by industry and that financed by government (federal, state, and/or local) but performed by industry are included. R\&D actually performed by the government, however, was not included.

R\&D data are collected from a sample of approximateiy 11,500 companies. These companies are chosen primarily from two sources; the fiscal Year 1981 Standard Statistical Estabiishment List and the Enterprise Statistical Multiunit File, which are compiled by the Bureau of the Census. The NSF uses the expenditure data from this sample to estimate expenditures for the entire population of industries.

The data collected from the NSF are presented in current dol lars in Table A. 1 of the Appendix.

\subsubsection{Description of Price Deflator}

The GNP implicit price deflator was used to defiate all R\&D expenditures into real, 1972 dollars. The price deflator is an index equal to 100 in 1972. It is a measure of the price level, similar to the more-familiar Consumer Price Index (CPI). It indexes the general price level of all of 
the goods and services produced in the United States, not just the price level of a typical "market basket" of consumer-purchased goods and services (as in the case of the CPI). The price deflator data used in the analys is are presented in Table A.2 of the Appendix. 


\subsection{ANALYSIS OF R\&D EXPENDITURE TRENDS}

Using the data base described in chapter 3.0, trends in real R\&D expenditures during the 1975-1982 period were analyzed for each of nine industries, as well as for all industries combined. All R\&D data presented in this section were deflated by the GNP implicit price deflator (1972 = 1.DO), and are thus measured in real, inflation-adjusted 1972 dollars. For all but three of the industries, (Petroleum, Aircraft and Missiles, and Professional and Scientific Instruments), trends in expenditures for al1 three types of R\&D were analyzed; for the three exceptions, trends in energy conservation R\&D expenditures could not be examined due to incomplete data series. Trends for the nine individual industries are examined in sections 4.1 through 4.9. Expenditure trends for all industries combined are described in section 4.10.

\subsection{CHEMICALS INDUSTRY}

Figures 4.1 (a), (b), and (c) show real R\&D expenditure trends for the Chemicals Industry (SIC 28). Real total R\&D expenditures increased at an annual average rate of .04 (i.e., 4 percent) during the 1975-1982 period. Year-to- year changes were fairly constant during the period, with a small decrease occurring in 1978 and annual increases accelerating in the 1980-1982 period. As shown in Figure 4.1 (b), real energy $R \& D$ expenditures also increased dramatically during the 1972-1982 period, at an annual average rate of .085 . Again, increases were fairly steady, with a small decrease in 1978. Energy conservation R\&D expenditures, however, demonstrate completely different behavior, as shown in Figure 4.1 (c). For the entire 1975-1982 period, real expenditures increased at an annual average rate of .185 . However, real expenditures increased at a much higher rate than this in the 1975-1980 period, then fell dramatically in 1981 and 1982.

Figures 4.1 (d) and (e) show real energy and energy conservation R\&D expenditures as a percentage of real total $R \& D$ expenditures for the industry. Energy's share of total R\&D expenditures increased from just below 4 percent in 1975 to approximately 5.5 percent in 1981, before falling slightly in 1982. Energy conservation's share of total R\&D expenditures 


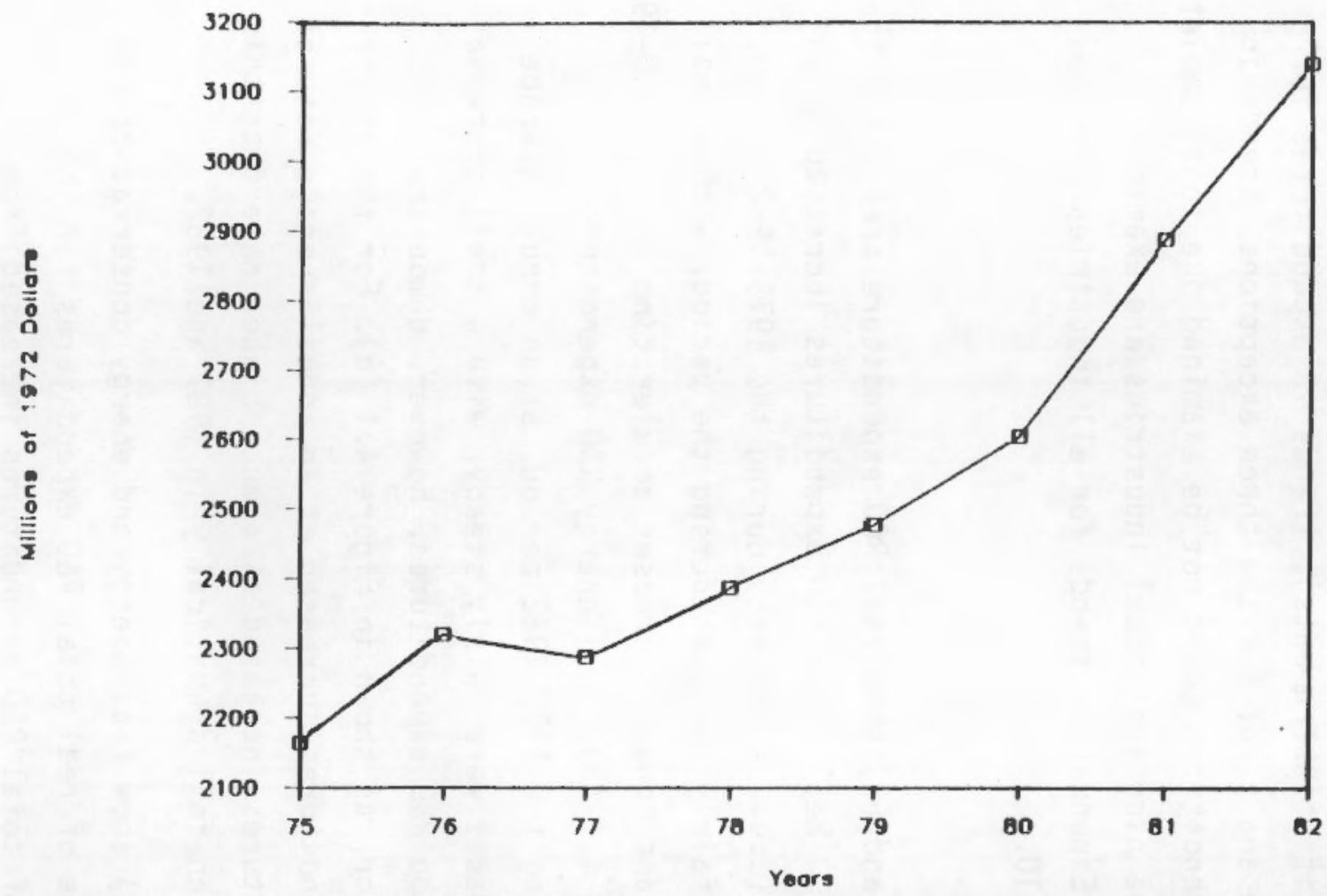

FIGURE 4.1(a). Total R\&D Expenditures, Chemicals Industrv.

SOURCE: National Science Foundation. 1984. R\&D in Industry: 1982 Detailed Statistical Tables.

FROM: Pactfic Northwest Laboratory. 1985. Recent Trends In Energy Research and Development Expenditures. 


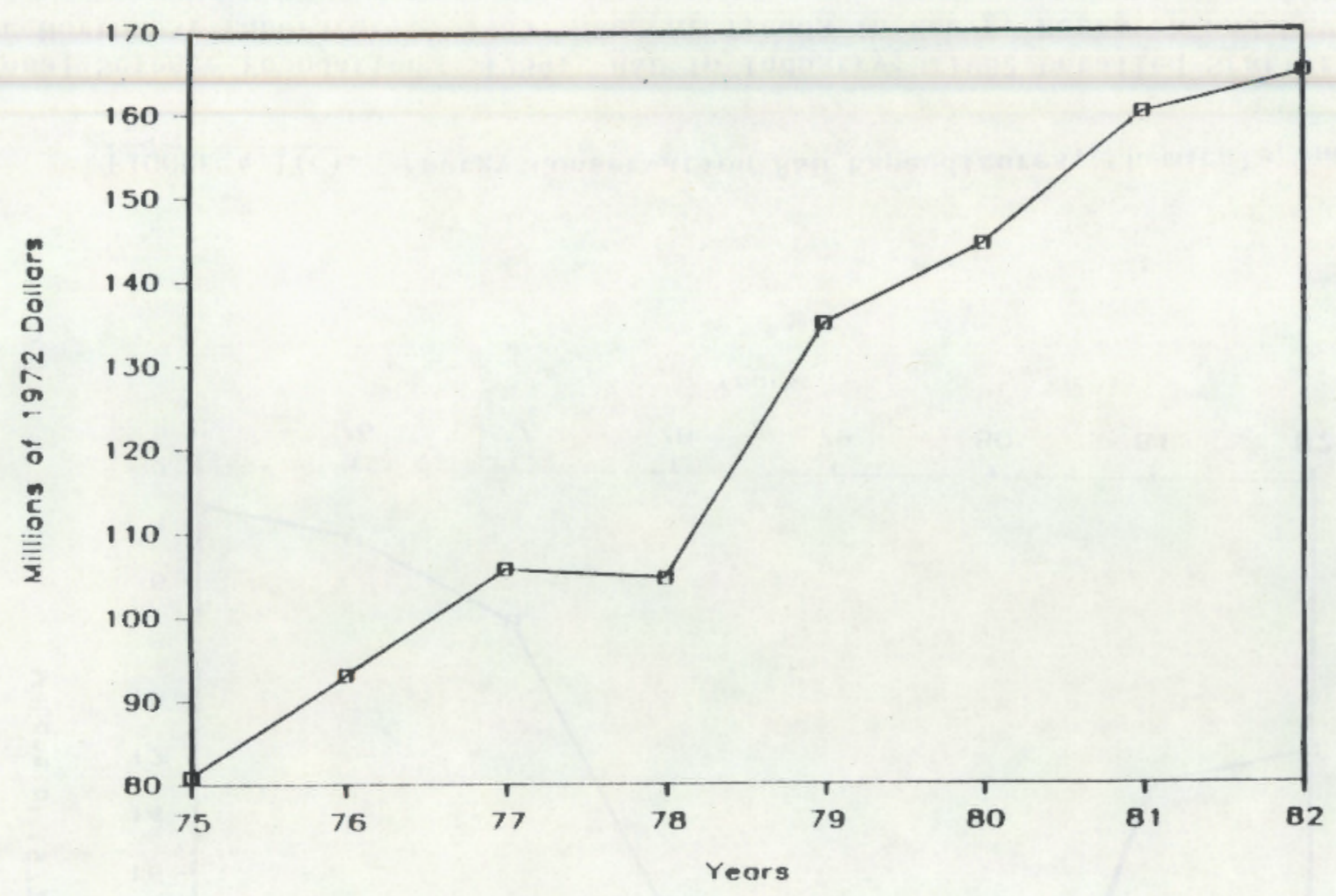

FIGURE 4.1(b). Energy R\&D Expenditures, Chemicals Industry.

SOURCE: National Science Foundation. 1984. R\&D in Industry: 1982 Detailed Statistical Tables.

FROM: Pacific Northwest Laboratory. 1985. Recent Trends in Energy Research and Development Expenditures. 




FIGURE 4.1(c). Energy Conservation R\&D Expenditures, Chemicals Industry.

SOURCE: National Science Foundation. 1984. Rod in Industry: 1982 Detalled Statistical Tables. FROM: Pacific Northwest Laboratory. 1985. Recent Trends in Energy Research and Development Expenditures. 




FIGURE 4.1(d). Energy R\&D Expenditures as a Percentage of Total R\&D Expenditures, Chemicals Industry.

SOURCE: National Science Foundation. 1984. R\&D in Industry: 1982 Deta1led Statistical Tables.

FROM: Pacif ic Northwest Laboratory. 1985. Recent Trends In Energy Research and Development Expenditures. 


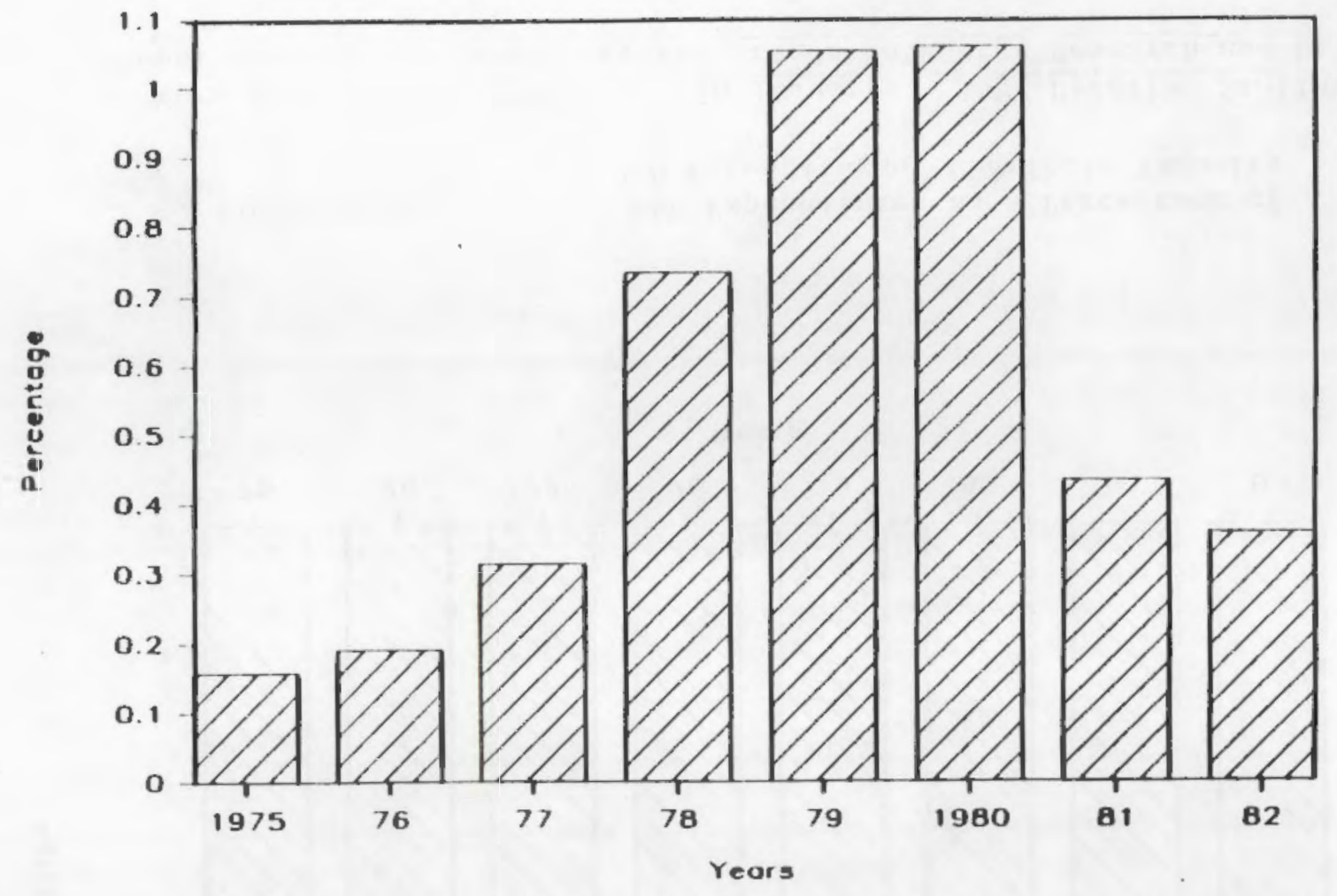

FIgURE 4.1(e). Energy Conservation RoD Expenditures as a Percentage of Total RdD Expenditures, Chemicals Industry.

SOURCE: National Science Foundation. 1984. R\&D in Industry: 1982 Detalled Statistical Tables. FROM: Pacific Northwest Laboratory. 1985. Recent Trends in Energy Research and Development Expenditures. 
increased dramatically between 1975 and 1980 (from less than .2 percent to more than 1 percent) before falling back to .3 percent in 1982 .

\subsection{PETROLEUM INDUSTRY}

Figures 4.2 (a) and (b) show real R\&D expenditure trends for the Petroleum Industry (SIC 29). Real total R\&D expenditures increased at an annual average rate of .076 during the 1975-1982 period, with accelerated increases in the 1977-1980 period, a slight decline in 1981, before an increase in 1982. As shown by Figure 4.2 (b), real energy R\&D expenditure increases were fairly steady, at an annual average rate of .083 , with a slight decline in expenditures in 1980.

Figure 4.2 (c) shows real energy R\&D expenditures as a percentage of real total R\&D expenditures. Energy's share of total R\&D remained fairly constant at 60 percent during the 1975-1982 period, with a slight decline in 1980 to approximtely 55 percent of total.

\subsection{PRIMARY METALS INDUSTRY}

Figures 4.3 (a), (b), and (c) show real R\&D expenditures trends for the Primary Metals Industry (SIC 33). Real total R\&D expenditures increased at an annual average rate of .045 during the 1975-1982 period, with small decreases in 1977 and 1978, and large increases in the 1978-1982 period. As shown by figure 4.3 (b), real energy R\&D expenditures varied considerably in the 1975-1982 period, although they increased at an annual average rate of .122 for the entire period. Expenditures decreased slightly in 1978 and 1981, but substantially increased in the years 1977, 1979, and 1982. As shown by Figure 4.3 (c), real energy conservation R\&D expenditures demonstrated remarkably different behavior from that of total and energy expenditures, increasing at an annual average rate of .204 , with dramatic increases between 1975 and 1977, and substantial decreases between 1980 and 1982.

Figures 4.3 (d) and (e) show real energy and energy conservation R\&D expenditures as a percentage of real total R\&D expenditures for the industry. Energy's share of total R\&D expenditures varied during the 1975-1982 period, dipping to 6 percent of total in 1975 and increasing to more than 11 percent of total in 1979, before falling slightly in the 


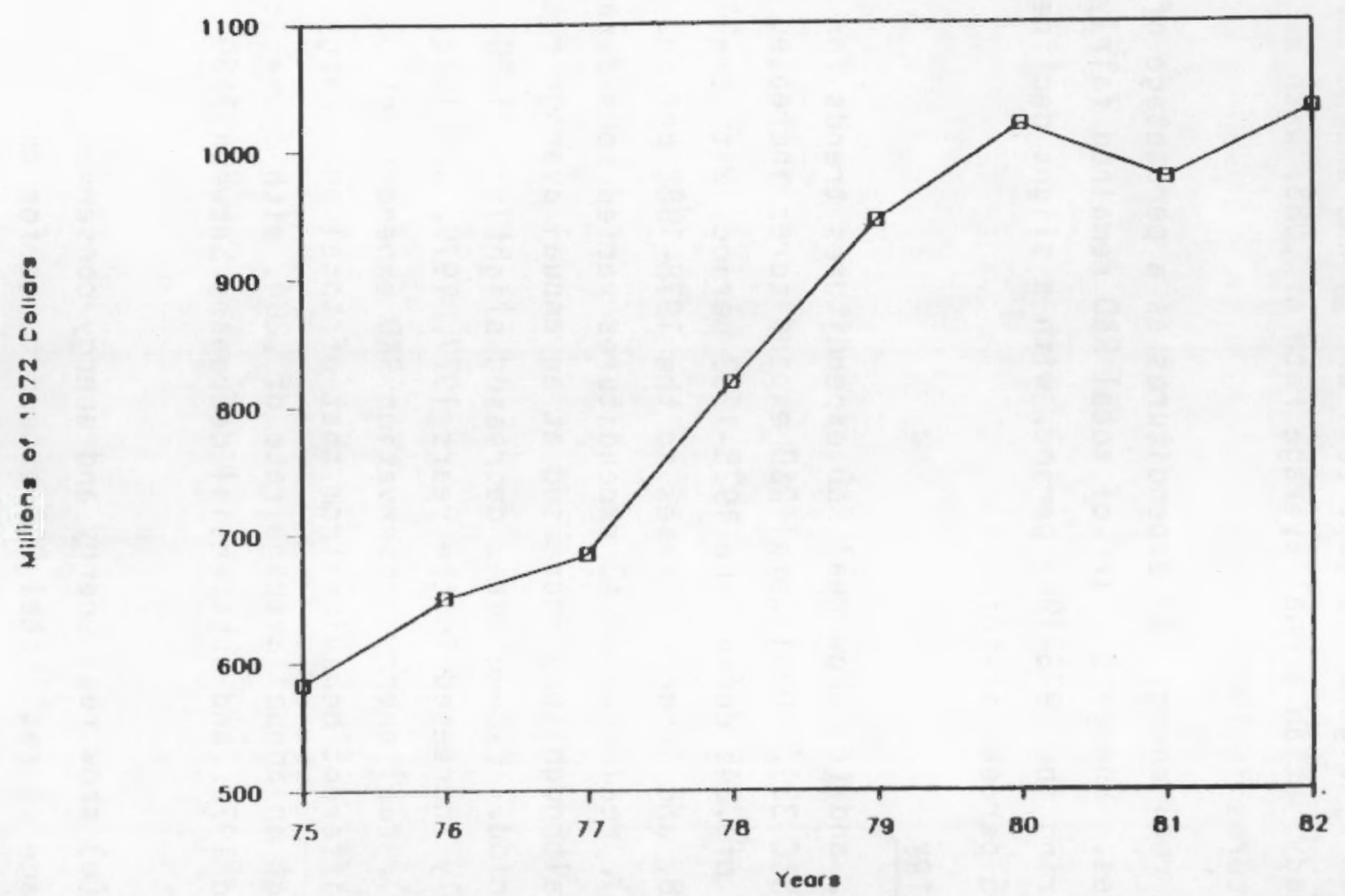

FICURE 4.2(a). Total R\&D Expenditures, Petroleum Industry.

SOURCE: National Science Foundation. 1984. R\&D in Industry: 1982 Detalled Statistical Tables.

FROM: Pacific Northwest Laboratory. 1985. Recent Trends in Energy Research and Development Expenditures. 


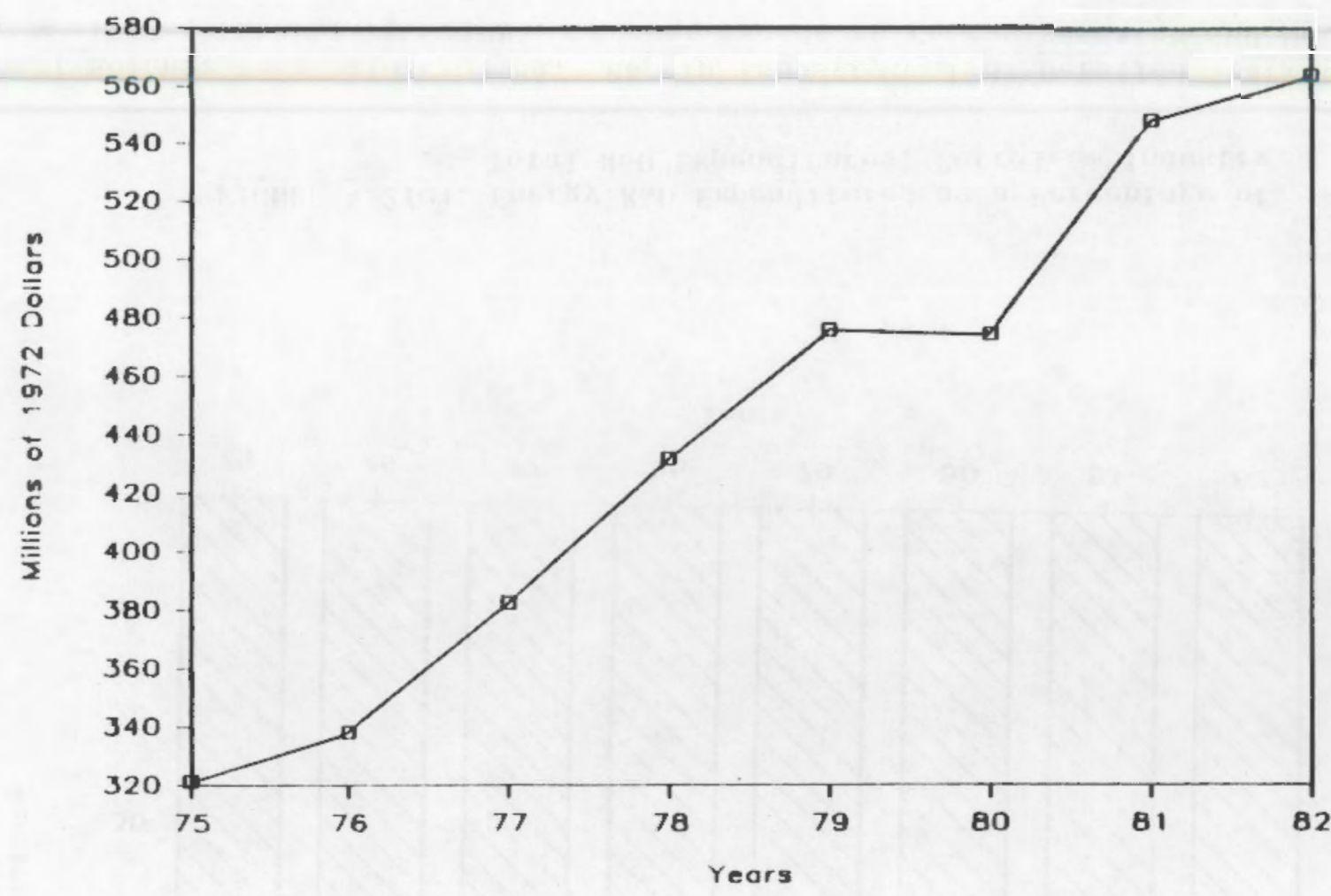

FICURE 4.2(b). Energy R\&D Expenditures, Petroleum Industry.

SOURCE: National Science Foundation. 1984. R\&D in Industry: 1982 Detafled Statistical Tables.

FROM: Pacific Northwest Laboratory. 1985. Recent Trends in Energy Research and Development Expenditures. 




PIGURE 4.2(c). Energy R\&D Expenditures as a Percentage of Total R\&D Expenditures, Petrolem Industry.

SOURCE: National Science Foundation. 1984. R\&D in Industry: 1982 Detailed Statistical Tables.

FROM: Pacific Northwest Laboratory. 1985. Recent Trends in Energy Research and Development Expenditures. 


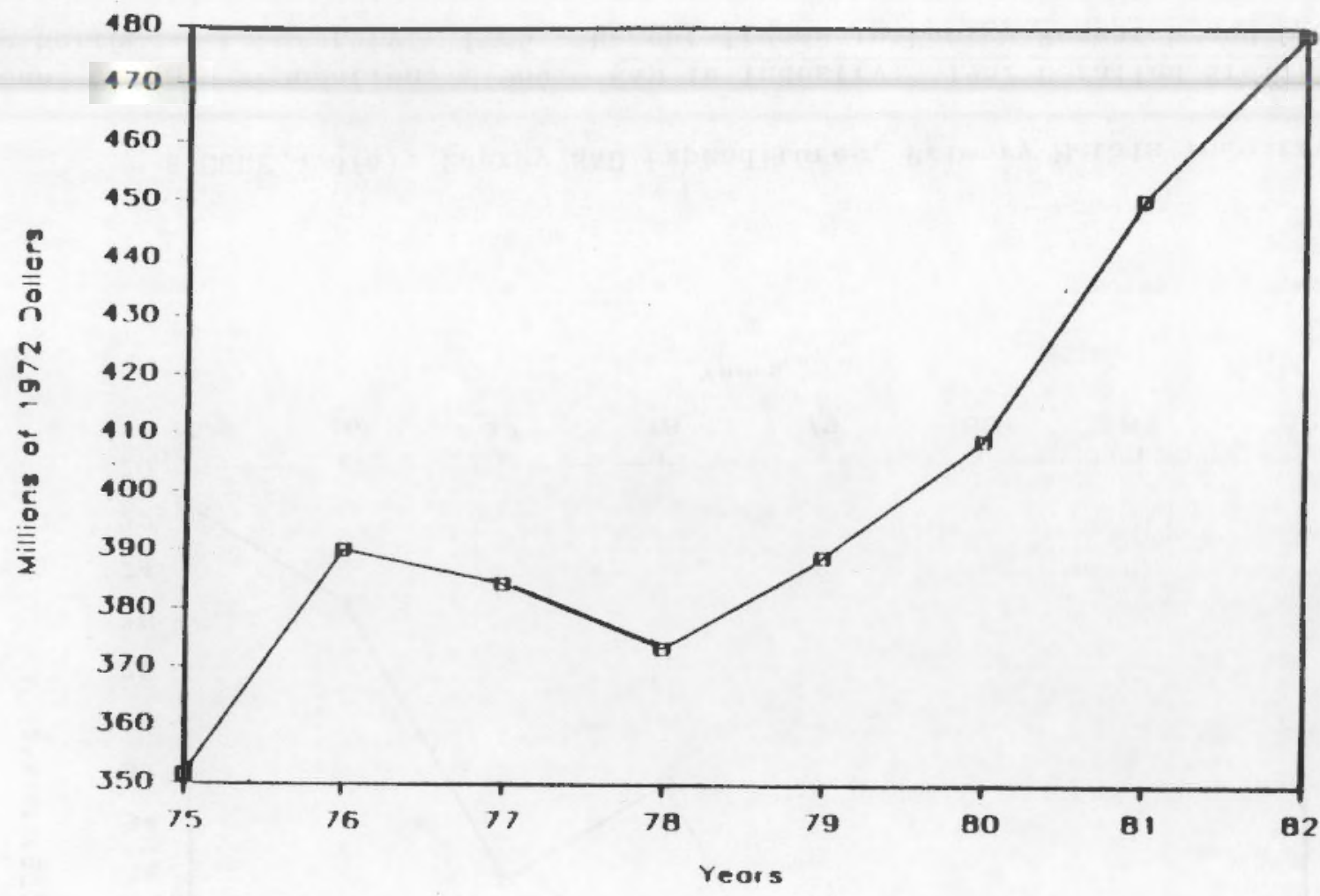

FIGURE 4.3(a). Total R\&D Expenditures, Primary Metals Industry.

SOURCE: Nattonal Science Foundation. 1984. R\&D In Industry: 1982 Detalled Statistical Tables. FROM: Pacif Ic Northwest Laboratory. 1985. Recent Trends In Energy Research and Development Expenditures. 




FIGURE 4.3 (b). Energy R\&D Expenditures, Primary Metals Industry.

SOURCE: National Science Foundation. 1984. R\&D in Industry: 1982 Detalled Stat1st1cal Tables.

FROM: Pacific Northwest Laboratory. 1985. Recent Trends in Energy Research and Development Expenditures. 


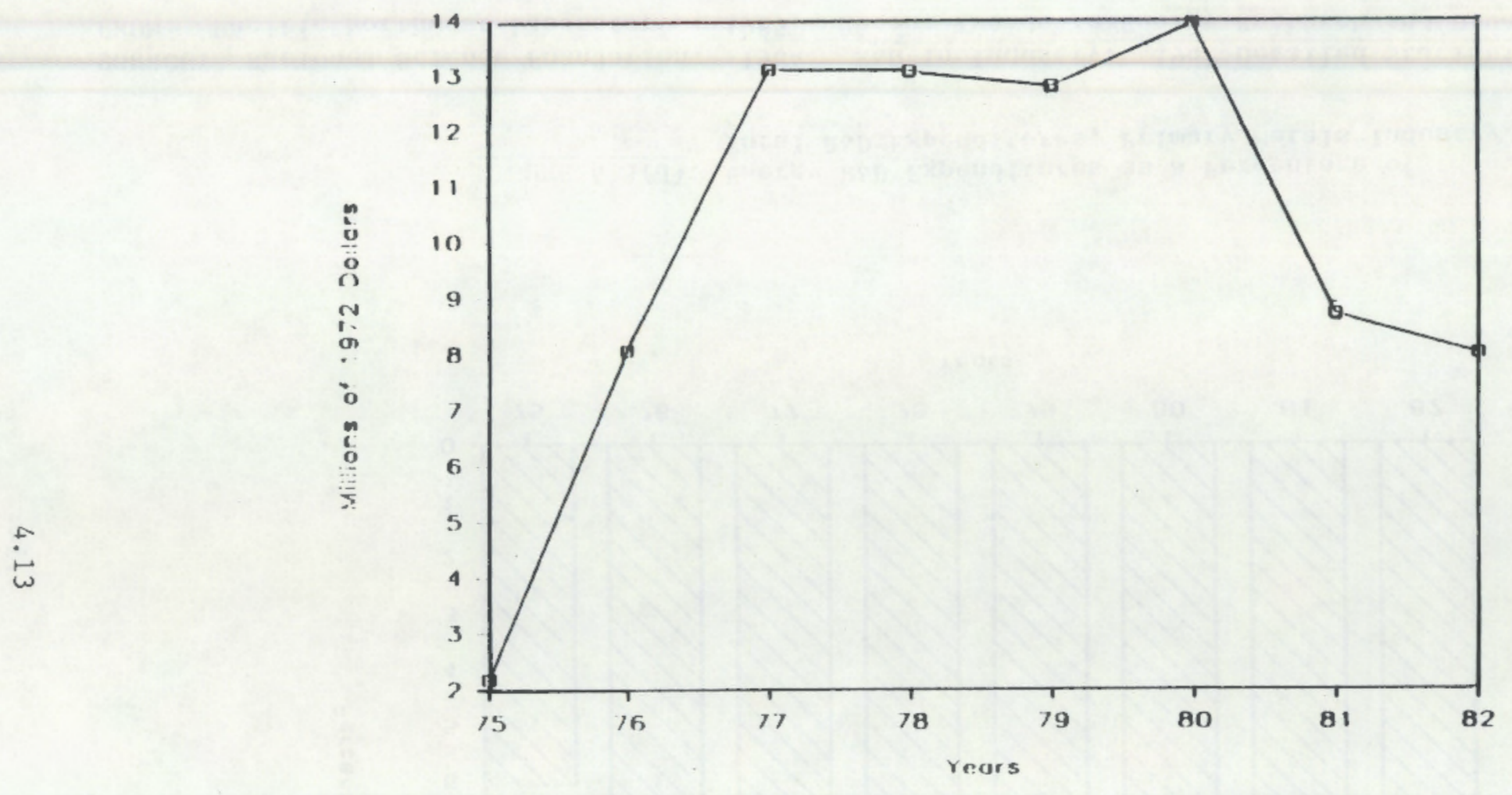

FIGURE 4.3(c). Energy Conservation R\&D Expenditures, Primary Metals Industry.

SOURCE: National Science Foundation. 1984. Rod In Industry: 1982 Detailed Statistical Tables. FROM: Pacific Northwest Laboratory. 1985. Recent Trends In Energy Research and Development Expenditures. 


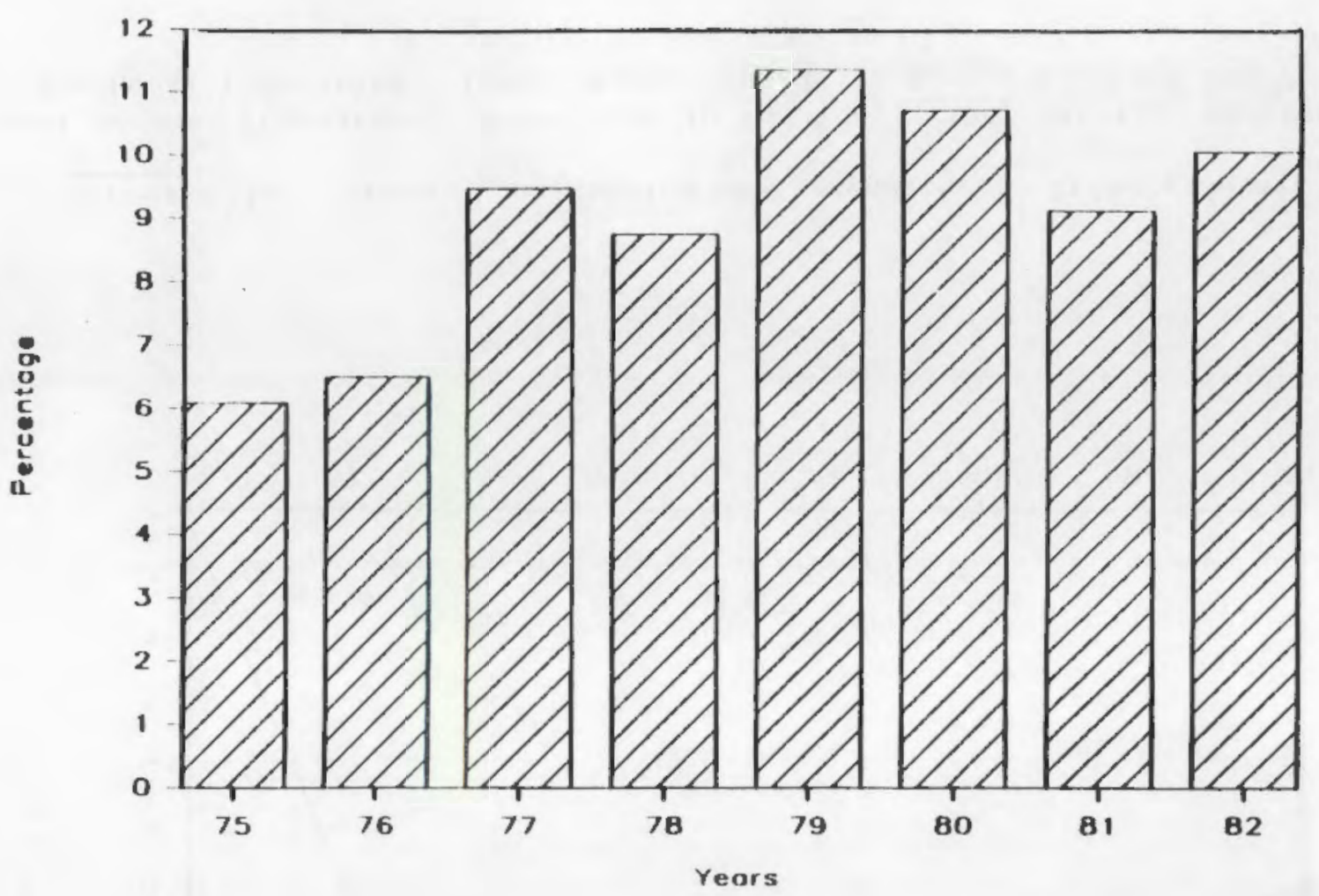

FIGURE 4.3(d). Energy R\&D Expenditures as a Percentage of

Total R\&D Expenditures, Primary Metals Industry.

SOURCE: National Science Foundation. 1984. R\&D in Industry: 1982 Detalled Stat1stical Tables.

FROM: Pacific Northwest Laboratory. 1985. Recent Trends in Energy Research and Development Expenditures. 


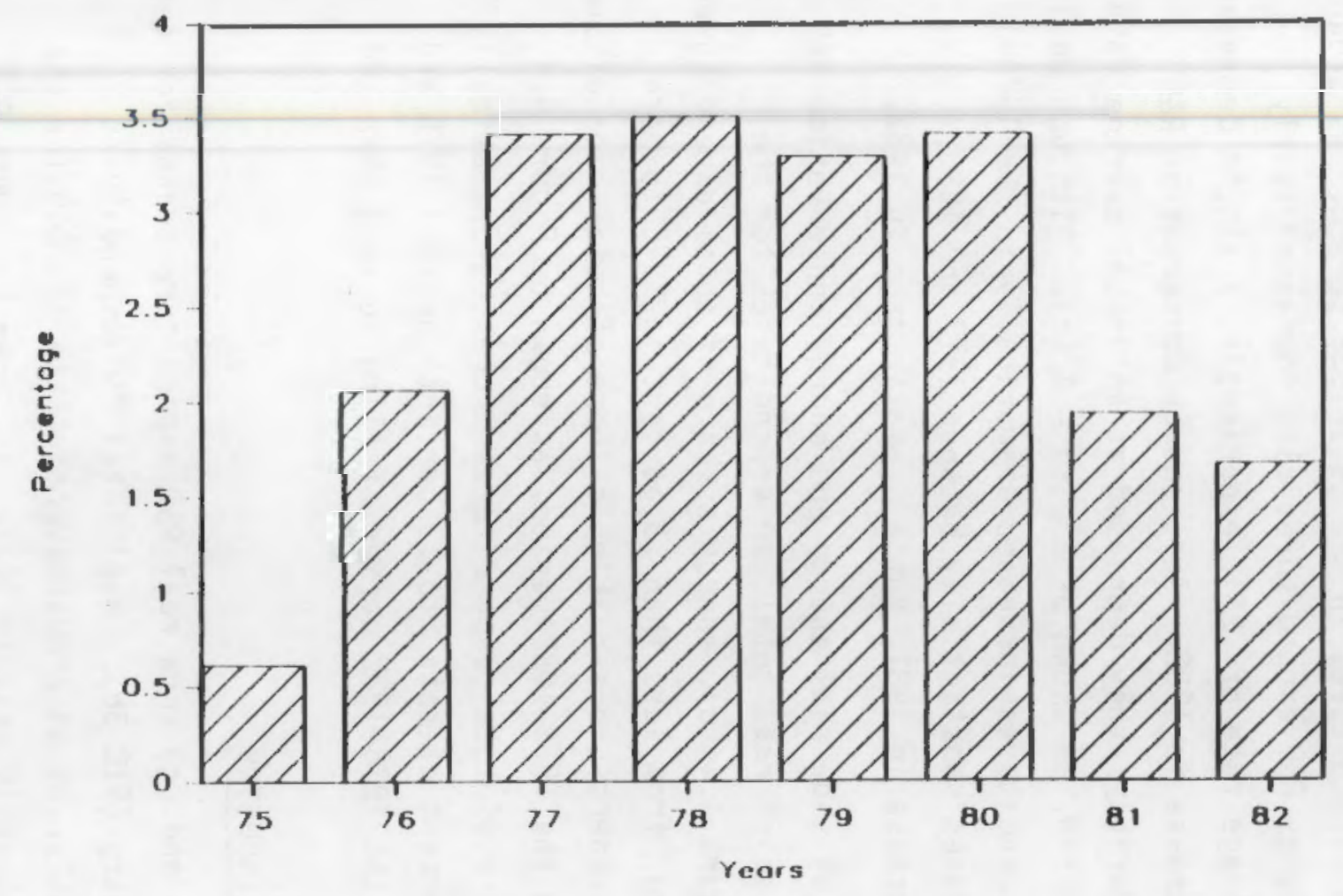

FIGURE 4.3(e). Energy Conservation R\&D Expenditures as a Percentage of Total R\&D Expenditures, Primary Metals Industry.

SOURCE: National Science Foundation. 1984. R\&D in Industry: 1982 Detailed Stat1stical Tables. FROM: Pacific Nortliwest Laboratory. 1985. Recent Trends in Energy Research and Development Expenditures. 
1980-1982 period. As shown by Figure 4.3 (e), energy conservation's share increased in the period between 1975 and 1978 to approximately 3.5 percent of total, then declined to approximately 1.8 percent in 1982.

\subsection{MACHINERY INDUSTRY}

Figures 4.4 (a), (b), and (c) show real R\&D expenditure trends for the Machinery Industry (SIC 35). Real total R\&D expenditures grew at a fairly steady rate between 1975 and 1982, at an annual average rate of 0.58 , with an accelerated increase in expenditures in the 1979-1982 period. As shown by Figure 4.4 (b), real energy $R \& D$ expenditures also increased fairly steadily, at an annual average rate of .261 , experiencing a slight decrease in 1979 and a dramatic increase in 1982. Rea 7 energy conservation $R \& D$ expenditures varied considerably; they decreased at an annual average rate of -.023 for the entire period, as shown by Figure 4.4 (c). Although real energy conservation R\&D expenditures increased dramatically in the 1975-1977 period, expenditures decreased substantially between 1977 and 1980, demonstrating a slight increase in 1981, but a dramatic drop in 1982.

Figures 4.4 (d) and (e) show real energy and energy conservation R\&D expenditures as a percentage of real total R\&D expenditures for the industry. As shown by Figure 4.4 (d), energy's share of total expenditures increased during the period, from less than .8 percent in 1975 to more than 2.4 percent in 1982. Energy conservation's share of total expenditures varied considerably during the 1975-1982 period, as shown by Figure 4.4 (e). The conservation share of total expenditures increased dramatically (from approximately .05 percent of total to .3 percent) between 1975 and 1977 before decreasing in the 1978-1982 period, falling to less than .04 percent in 1982.

\subsection{ELECTRICAL EQUIPMENT INDUSTRY}

Figures 4.5 (a), (b), and (c) show real R\&D expenditure trends for the Electrical Equipment Industry (SIC 36). Real total R\&D expenditures increased fairly consistently, at an annual average rate of .049 for the entire period, declining slightly only in 1977. As shown by Figure 4.5 (b), real energy $R \& D$ expenditures varied considerably during the period, although they increased at an annual average rate of .017 for the 


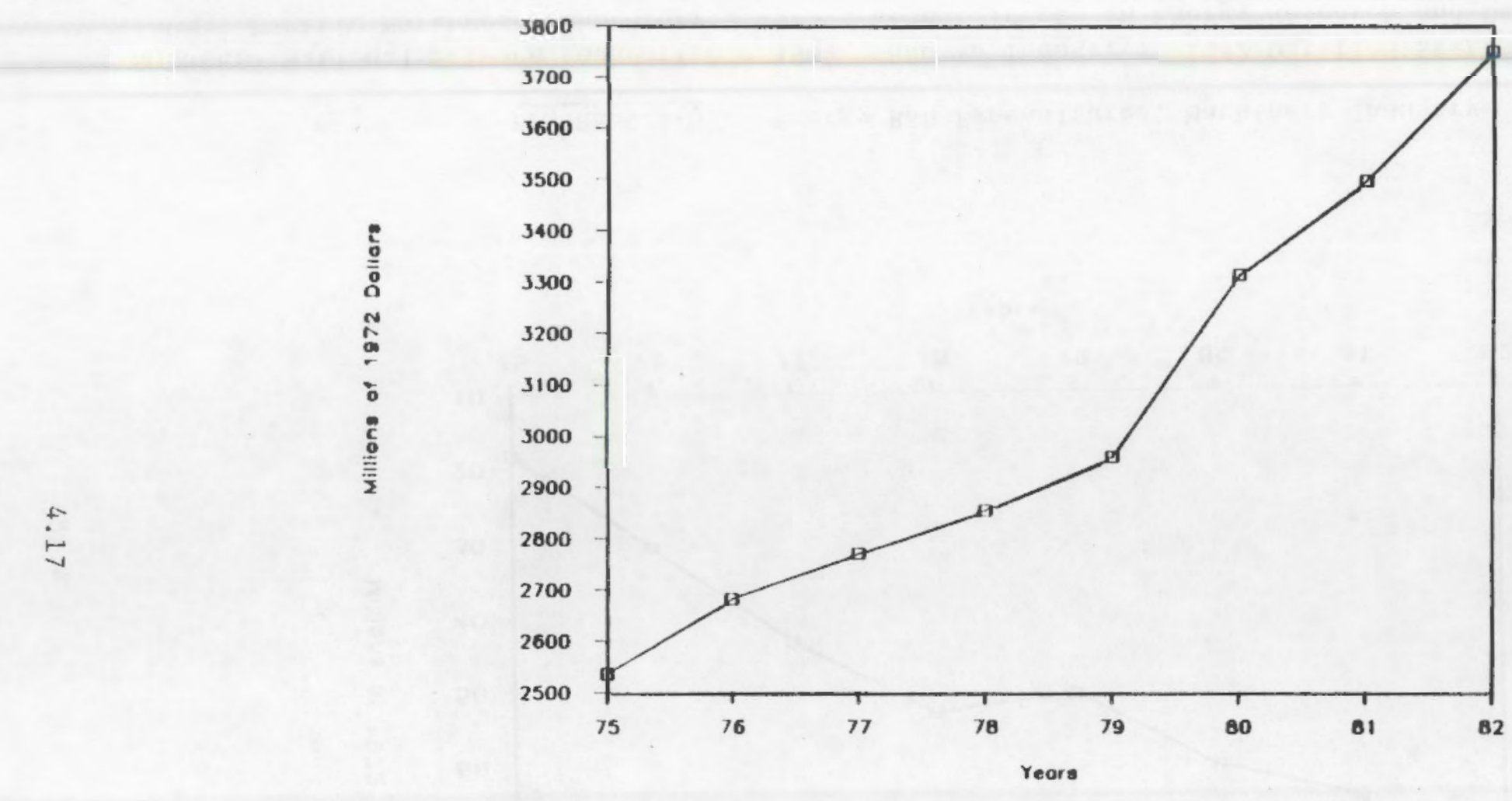

FIGURE 4.4(a). Total R\&D Expenditures, Machinery Industry.

SOURCE: National Science Foundation. 1984. R\&D In Industry: 1982 Detailed Statistical Tables.

FROM: Pacific Northwest Laboratory. 1985. Recent Trends in Energy Research and Development Expenditures. 




FIGURE $4.4(\mathrm{p})$. Energy R\&D Expenditures, Machinery Industry.

SOURCE: National Science Foundation. 1984. R\&D in Industry: 1982 Detailed Statistical Tables. FROM: Pacific Northwest Laboratory. 1985. Recent Trends in Energy Research and Development Expenditures. 




FIGURE 4.4(c). Energy Conservation R\&D Expenditures, Machinery Industry.

SOURCE: National Science Foundation. 1984. R\&D in Industry: 1982 Detailed Statistical Tables.

FROM: Pacific Northwest Laboratory. 1985. Recent Trends in Energy Research and Development Expenditures. 




FICURE $4.4(d)$. Energy R\&D Expenditures as a Percentage of Total R\&D Expenditures, Machinery Industry.

SOURCE: National Science Foundation. 1984. R\&D in Industry: 1982 Detafled Statistical Tables. FRuM: Pacific Nortliwest laboratory. 1985. Recent Trends in Energy Research and Development Expenditures. 




FIGUIE 4.4(e). Energy Conservation R\&D Expenditures as a Percentage of Total RoD Expenditures, Machinery Industry.

SOURCE: National Science Foundation. 1984. R\&D in Industry: 1982 Detafled Stat1stical Tables.

FROM: Pacific Northwest Laboratory. 1985. Recent Trends in Energy Research and Development Expenditures. 


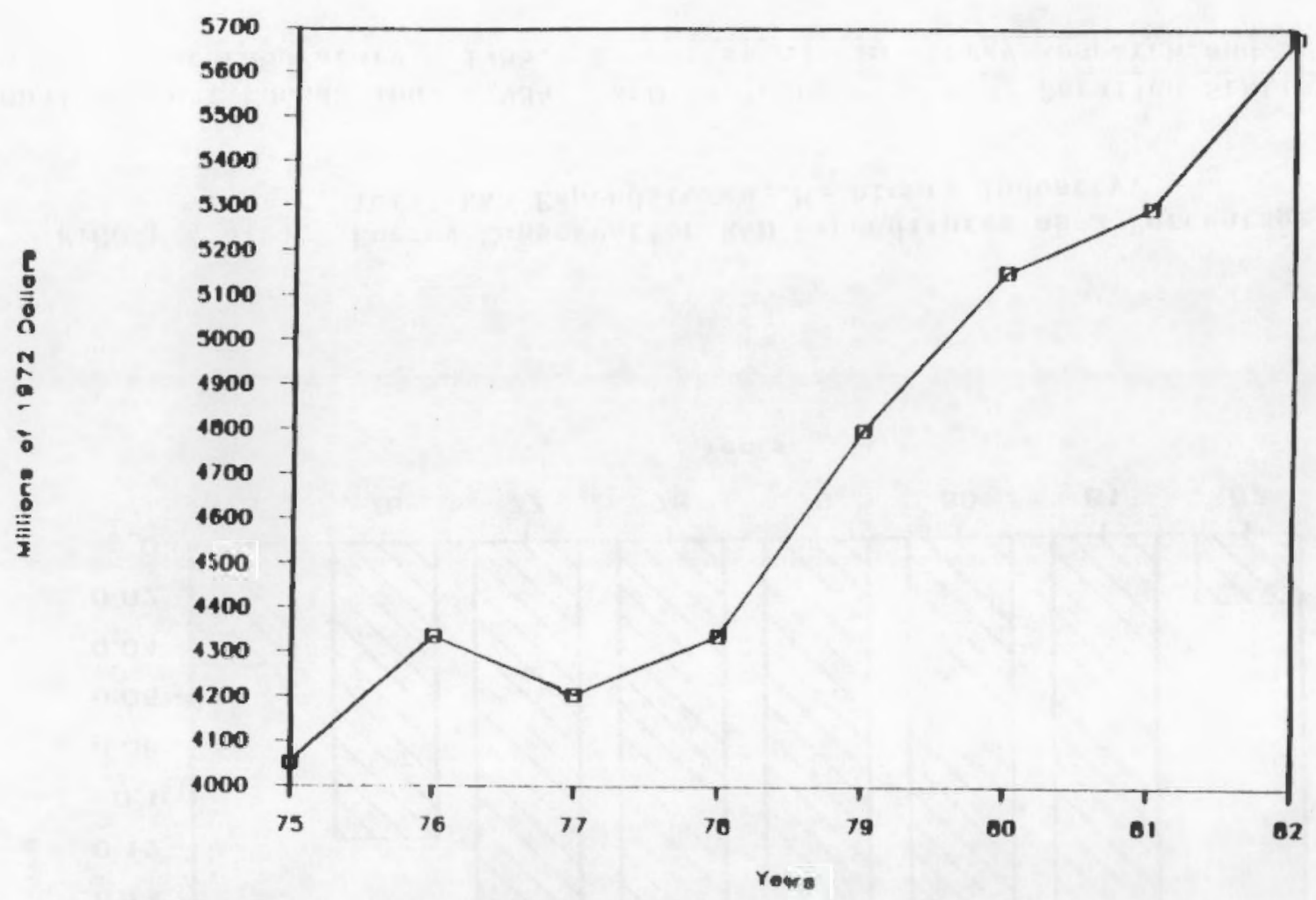

FIGURE 4,5(a). Total R\&D Expenditures, Electrical Equipment Industry.

SOURCE: National Science Foundation. 1984. R\&D In Industry: 1982 Detalled Stat1stical Tables.

FROM: Pacif ic Northwest Laboratory. 1985. Recent Trends in Energy Research and Development Expenditures. 


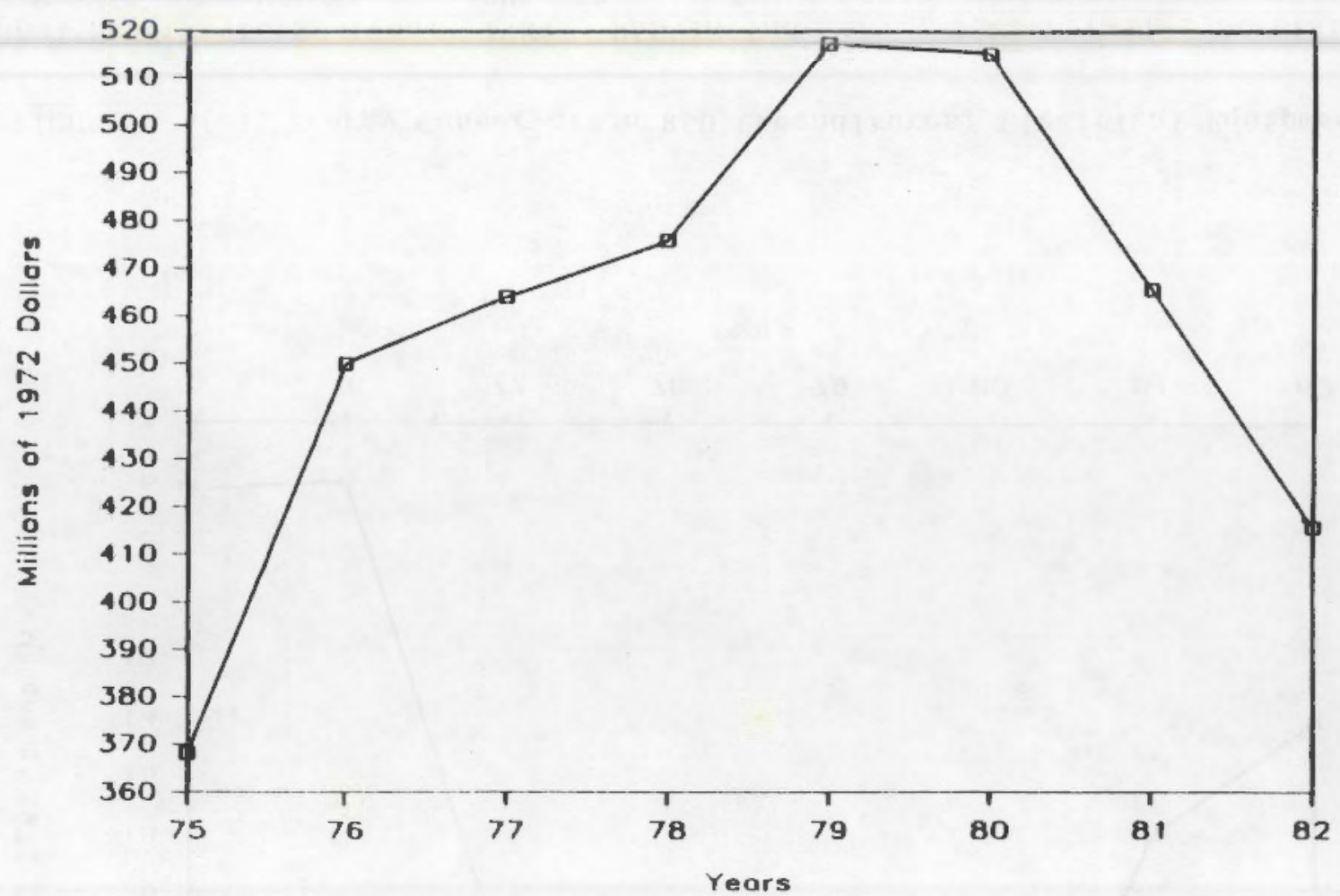

FIGURE 4.5(b). Energy R\&D Expenditures, Electrical Equipment Industry.

SOURCE: National Science Foundation. 1984. R\&D in Industry: 1982 Detalled Statistical Tables.

FROM: Pacific Northwest Laboratory. 1985. Recent Trends in Energy Research and Development Expenditures. 


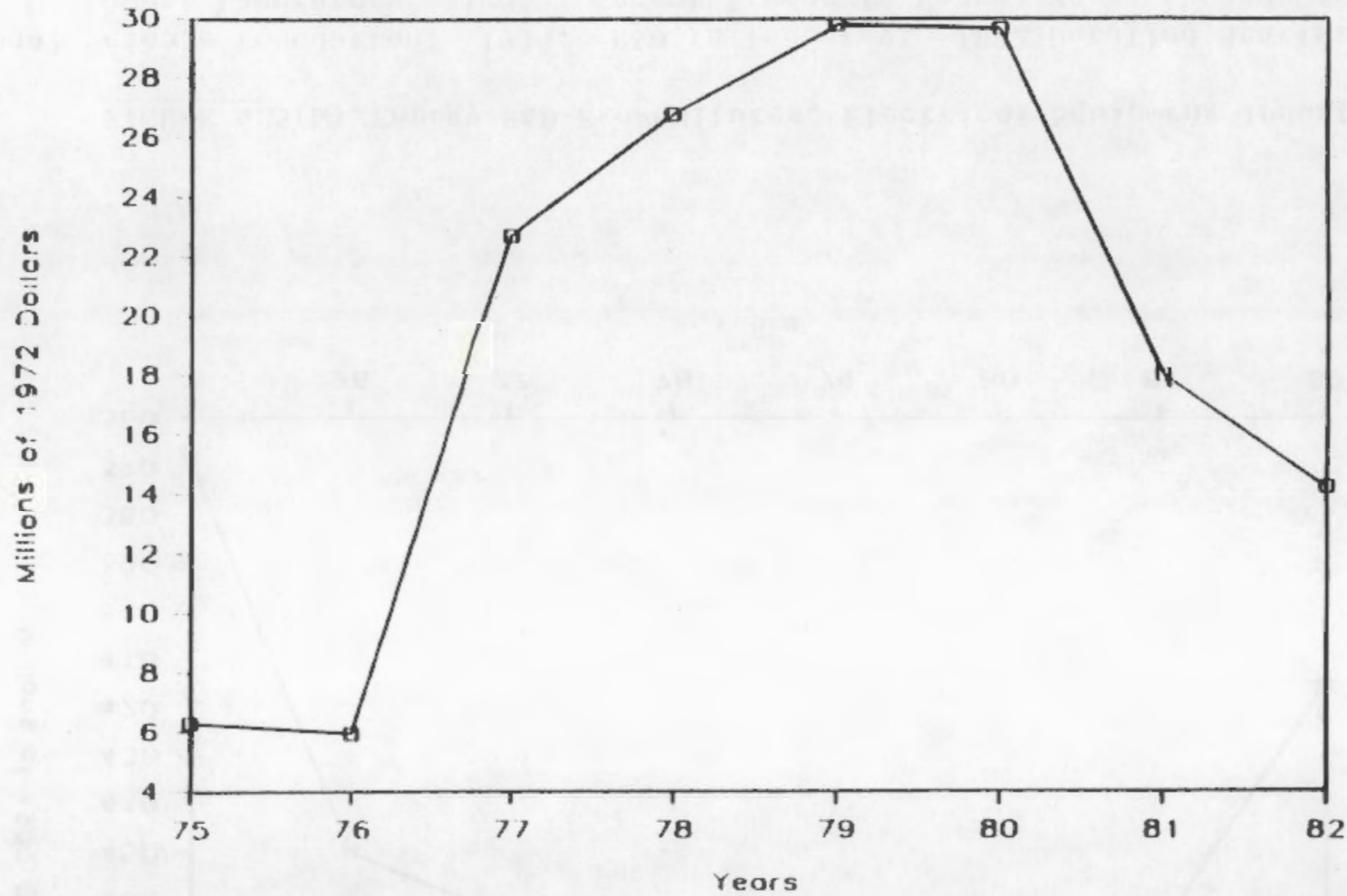

FIGURE 4.5(c). Energy Conservation R\&D Expenditures, Electrical Equipment Industry.

SOURCE: National Science Foundation. 1984. R\&D in Industry: 1982 Detalled Statistical Tables.

FROM: Pacific Northwest Laboratory. 1985. Recent Trends in Energy Research and Development Expenditures. 
period as a whole. Substantial increases occurred during the 1975-1979 period, but very large decreases took place during the 1980-1982 period. Similarily, real energy conservation R\&D expenditures varied during the 1975-1982 period, as shown by Figure 4.5 (c). For the period as a whole, expenditures increased at an average annual rate of .124 . However, expenditures increased at a considerably higher rate between 1976 and 1979. before declining substantially between 1980 and 1982 .

Figures 4.5 (d) and (e) show real energy and energy conservation R\&D expenditures as a percentage of real total R\&D expenditures. As shown by Figure 4.5 (d), energy's share of total was highest in the period between 1977 and 1979 at approximately 11 percent; it declined between 1979 and 1982 , falling to less than 8 percent in 1982. Similarily, as shown by Figure $4.5(e)$, energy conservation's share increased dramatically in 1977, from less than .2 percent to more than .5 percent, then decreased almost as dramatically between 1980 and 1982 .

\subsection{AIRCRAFT AND MISSILE INDUSTRY}

Figures 4.6 (a) and (b) show rea 1 R\&D expenditure trends for the Aircraft and Missile Industry (SICs 372 and 376). Real total R\&D expenditures increased at an annual average rate of .057 , with a slight decline in 1979, followed by large increases in 1981 and 1982. As shown by Figure 4.6 (b), real energy R\&D expenditures increased at an annual average rate of .067 , increasing substantially between 1976 and 1980 , before decreasing in 1981 and 1982.

Figure 4.6 (c) shows real energy R\&D expenditures as a percentage of real total R\&D expenditures. Energy's share of total increased substantially in the period between 1976 and 1980, from less than 2 percent to almost 5 percent, before falling back to approximately 2 percent in 1982.

\subsection{PROFESSIONAL AND SCIENTIFIC INSTRUMENTS INDUSTRY}

Figures 4.7 (a) and (b) show real $R \& D$ expenditure trends for the Professional and Scientific Instruments Industry (SIC 38). Real total R\&D expenditures consistently increased between 1975 and 1982, at an annual average rate of .11 . As shown by Figure 4.7 (b), real energy R\&D expenditures varied tremendously between 1975 and 1982, but for the entire period 


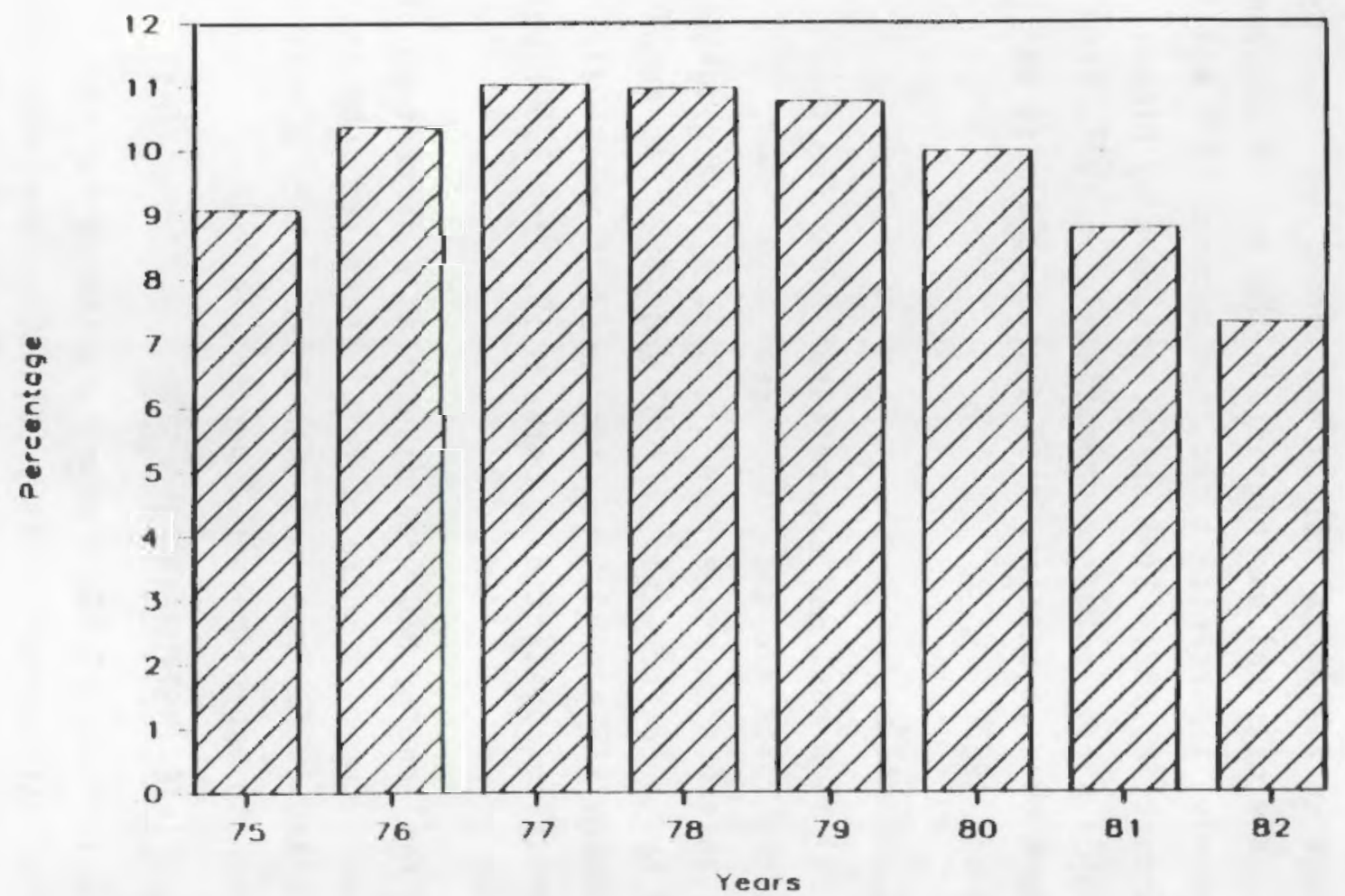

FICURE 4.5(d). Energy R\&D Expenditures as a Percentage of

Total K\&D Expenditures, Electrical Equipment Industry.

SOURCE: National Science Foundation. 1984. R\&D in Industry: 1982 Detalled Statist1cal Tables.

FROM: Pacific Northwest Laboratory. 1985. Recent Trends in Energy Research and Development Expenditures. 


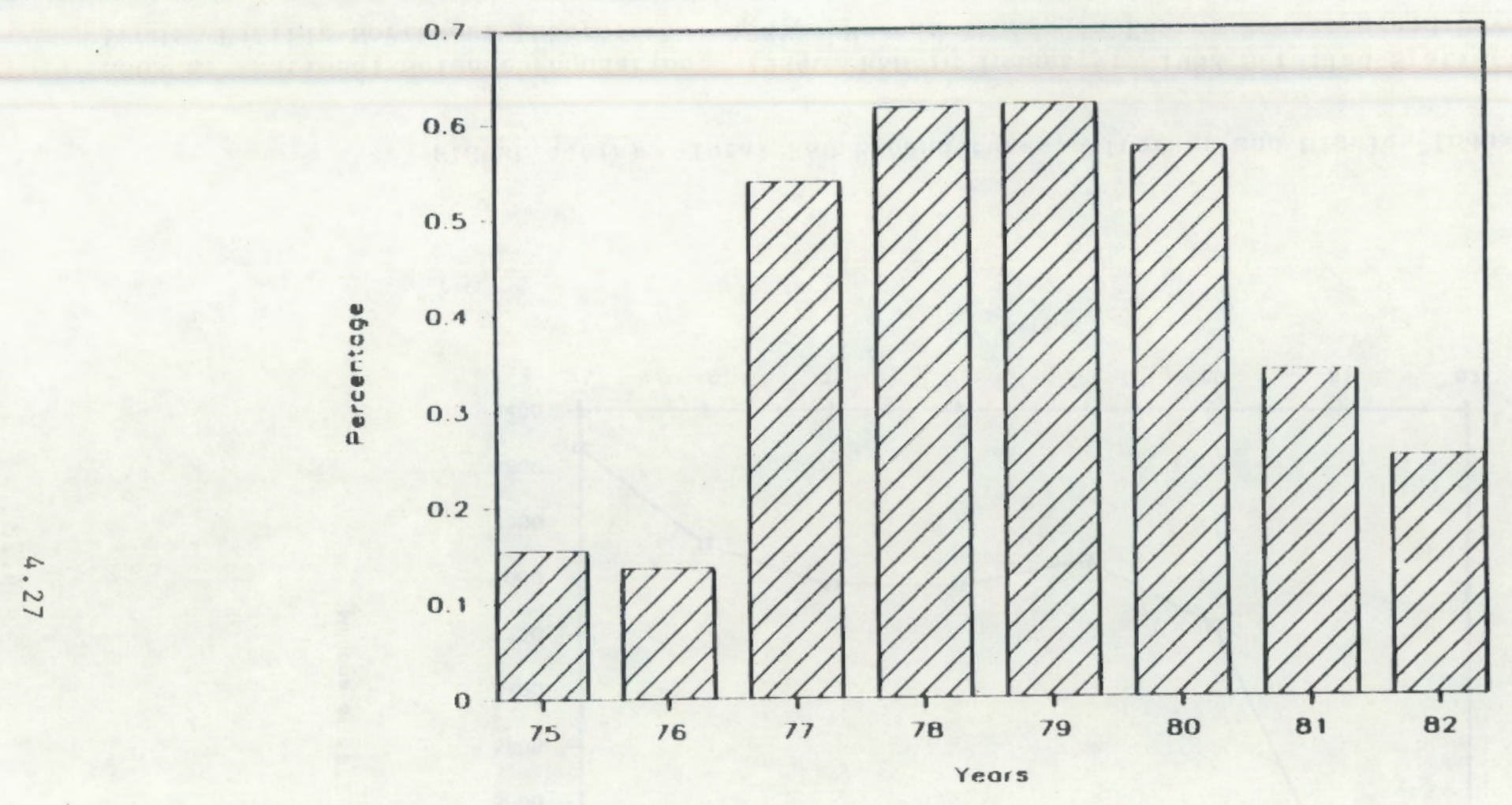

FICURE 4.5(e). Energy Conservation R\&D Expenditures as a Percentage of Total R\&D Expenditures, Electrical Equipment Industry.

SOURCE: National Science Foundation. 1984. R\&D in Industry: 1982 Detafled Statistical Tables.

FROM: Pacific Northwest Laboratory. 1985. Recent Trends in Energy Research and Development Expenditures. 


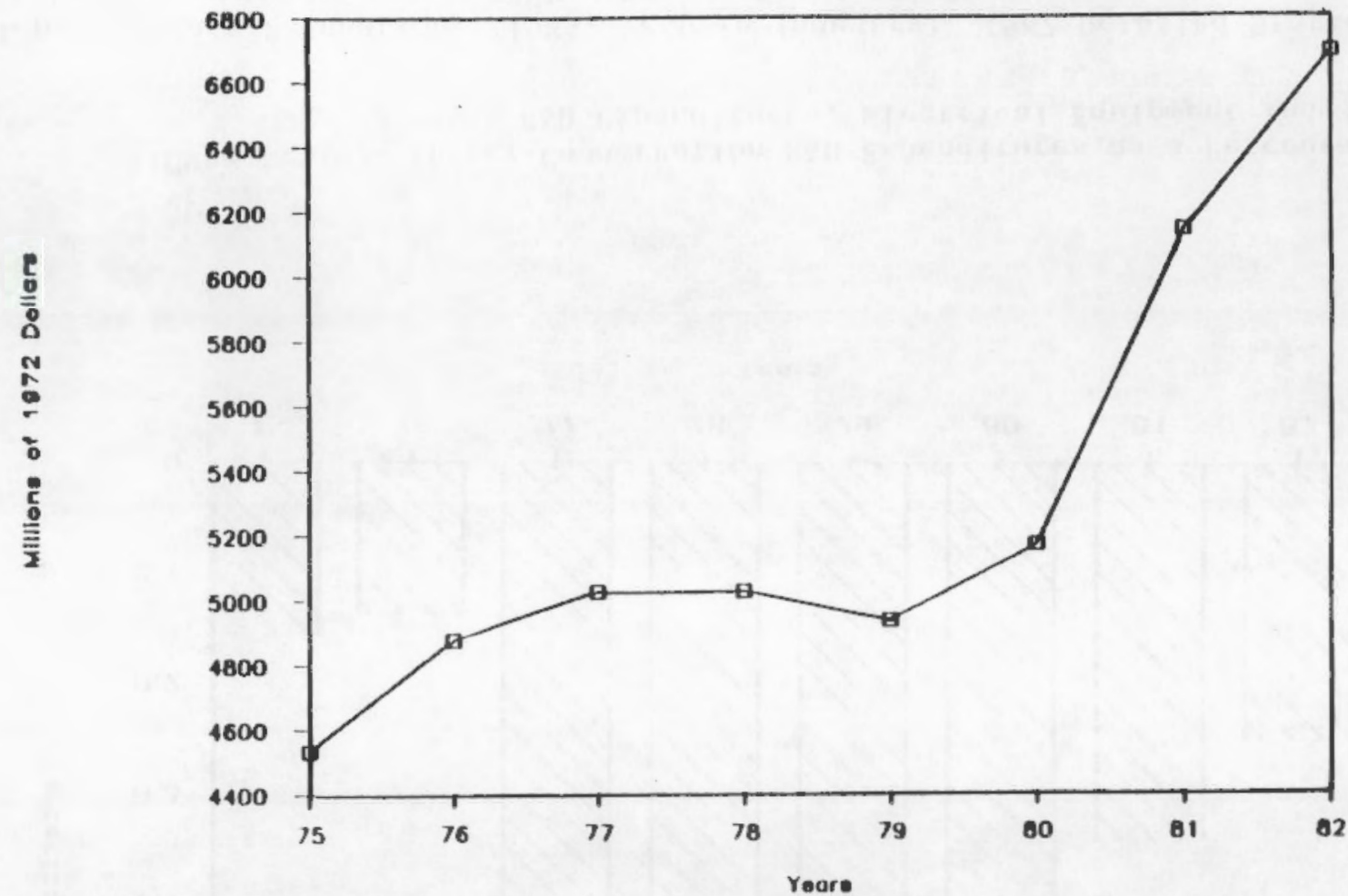

FICURE 4.6(a). Total R\&D Expenditures, A1rcraft and Missles Industry.

SOURCE: National Science Foundation. 1984. R\&D in Industry: 1982 Detalled Statist1cal Tables.

FROM: Pacific Northwest Laboratory. 1985. Recent Trends in Energy Research and Development Expenditures. 


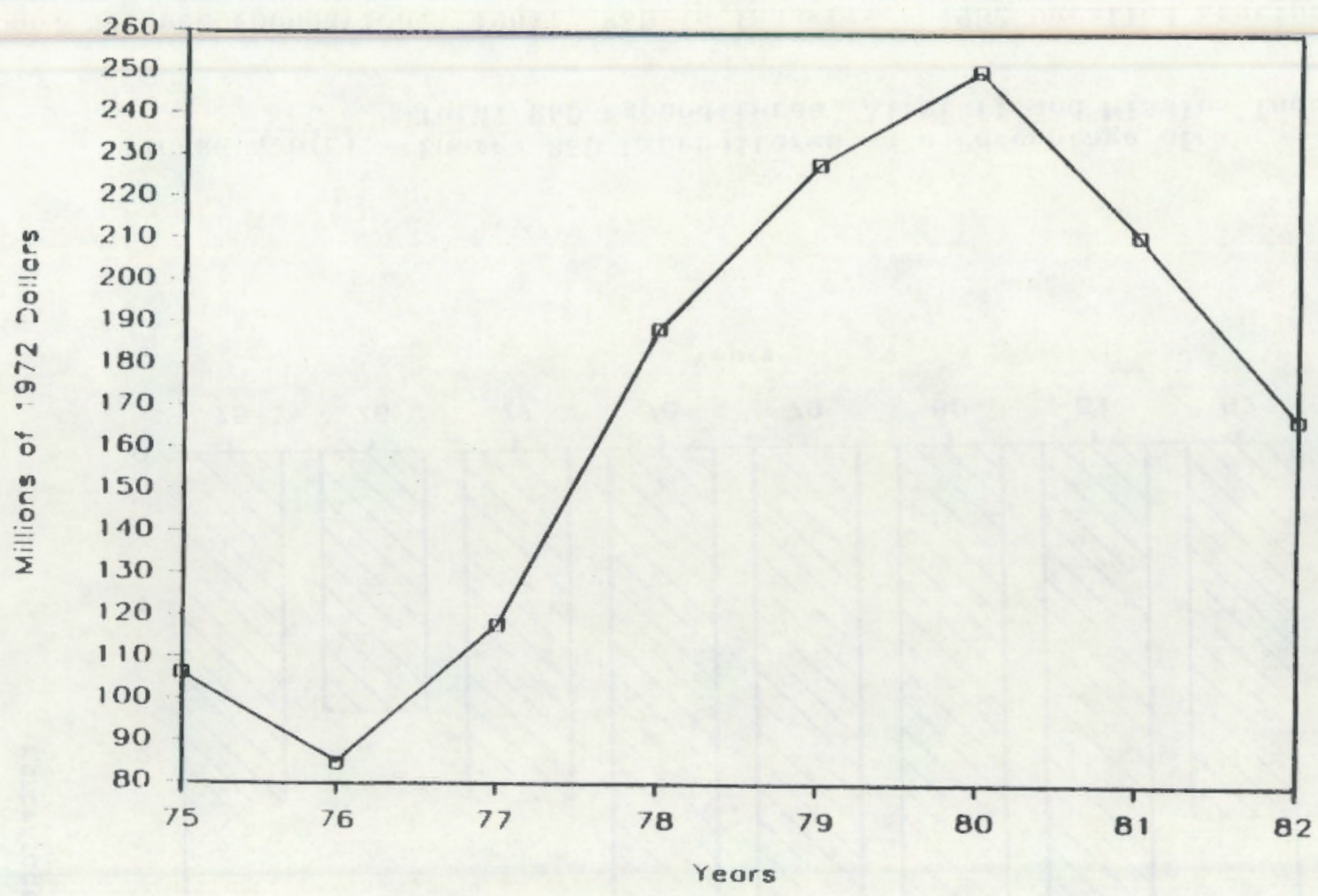

FIGURE 4.6(h). Energv R\&D Expenditures. Alroraft and Missles Industry.

SOURCE: National Science Foundation. 1984. R\&D in Industry: 1982 Detalled Statistical Tables. FROM: Pacific Northwest Laboratory. 1985. Recent Trends in Energy Research and Development Expenditures. 


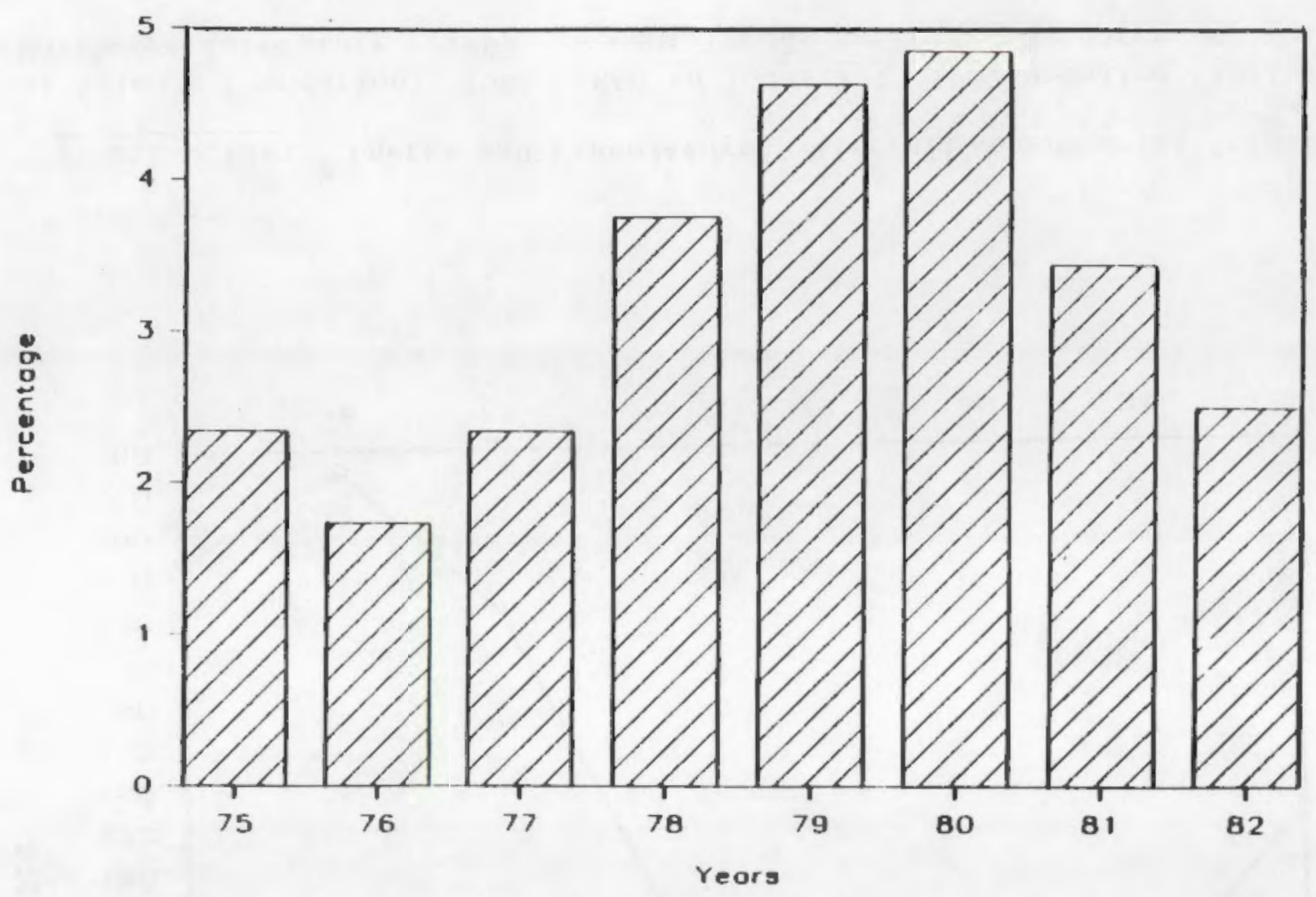

FICURE 4.6(c). Energy R\&D Expenditures as a Percentage of Total R\&D Expenditures, Aircraft and Hissles Industry.

SOURCE: National Science Foundation. 1984. R\&D in Industry: 1982 Detalled Statistical Tables.

FROM: Pacific Northwest Laboratory. 1985. Recent Trends in Energy Research and Development Expenditures. 


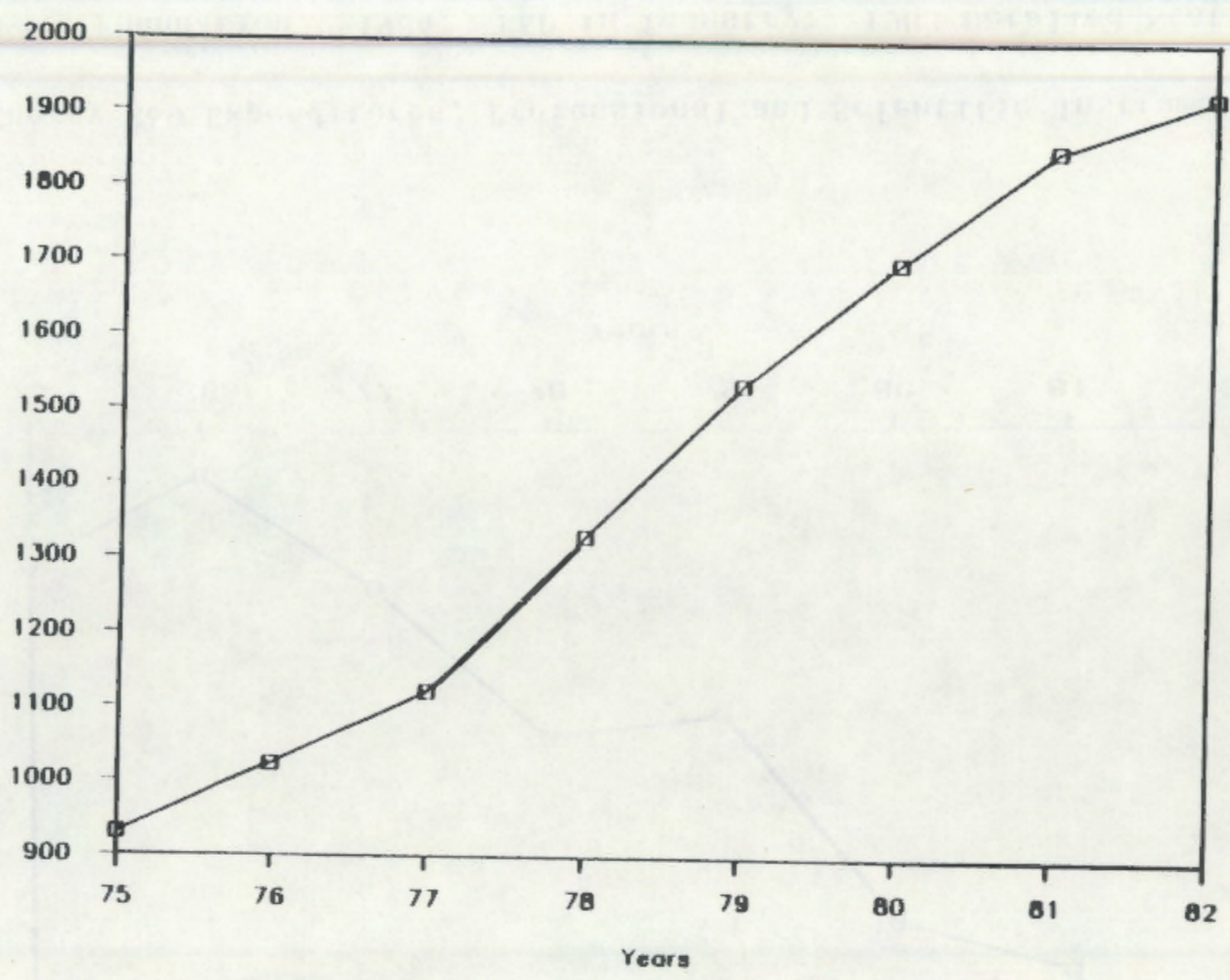

FIGURE 4.7(a). Total R\&D Expenditures, Professional and Scientific Instruments Industry.

SOURCE: National Science Foundation. 1984. R\&D in Industry: 1982 Detalled Statist1cal Tables.

FROM: Pacific Northwest Laboratory. 1985. Recent Trends in Energy Research and Development Expenditures. 


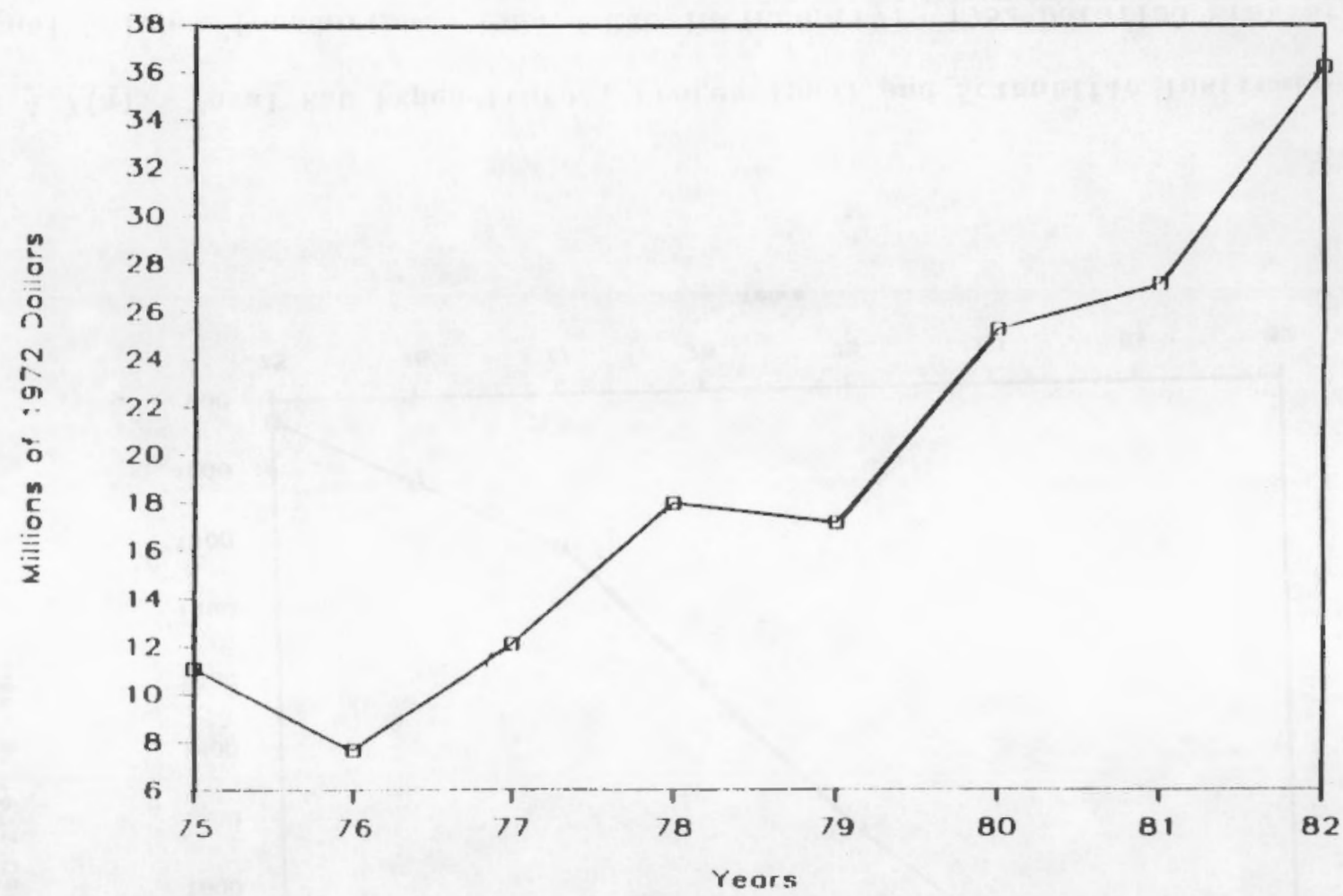

FIGURE 4.7(b). Energy R\&D Expenditures, Professional and Scientific Instruments Industry.

SOURCE: National Science Foundation. 1984. R\&D in Industry: 1982 Detafled Statistical Tables. FROM: Pacific Northwest Laboratory. 1985. Recent Trends in Energy Research and Development Expenditures. 
increased at an annual average rate of .184 .

Figure 4.7 (c) shows real energy R\&D expenditures as a percentage of real total R\&D expenditures. Energy's percentage of total varied in the period between 1975 and 1982, with energy's share of total equal to .7 percent in 1976 and approximately 1.9 percent in 1982.

\subsection{OTHER MANUFACTURING INDUSTRIES}

Figures 4.8 (a), (b), and (c) show real R\&D expenditure trends for Other Manufacturing Industries. Real total R\&D expenditures increased at an annual average rate of .036 for the entire period, increasing substantially between 1975 and 1980, before falling in 1981 and 1982. As shown by Figure 4.8 (b), real energy R\&D expenditures varied considerably during the 1975-1982 period, increasing at an annual average rate of .002. Expenditures increased dramatically in the 1975-1980 period, with a slight decline in 1978, followed by dramatic decreases in 1981 and 1982. Following a similiar pattern, as shown by Figure 4.8 (c), real energy conservation R\&D expenditures increased at an average annual rate of .074. Real energy conservation R\&D expenditures peaked in 1978, and decreased substantially in the period between 1978 and 1982.

Figures 4.8 (d) and (e) show real energy and energy conservation R\&D expenditures as a percentage of real total R\&D expenditures for the industry. Energy's share of total remained fairly constant between 1975 and 1980, but decreased in 1981 and 1982. As shown by Figure 4.8 (e). energy conservation's share of total increased between 1977 and 1979, peaking in 1979 at 2.6 percent, before falling to less than 1 percent in 1982.

\subsection{NONMANUFACTURING INDUSTRIES}

Figures 4.9 (a), (b), and (c) show real R\&D expenditure trends for all Nonmanufacturing Industries. Real total R\&D increased consistently in the 1975-1982 period, at an annual average rate of .085. Real expenditures declined only in 1981. As shown by Figure 4.9 (b), real energy expenditures increased at an annual average rate of .127 for the entire period, increasing dramatically in the period between 1975 and 1979, before falling off slightly in the 1980-1982 period. Similarly, as shown by Figure 4.9 (c), real energy conservation R\&D expenditures increased at an annual average rate of .26 


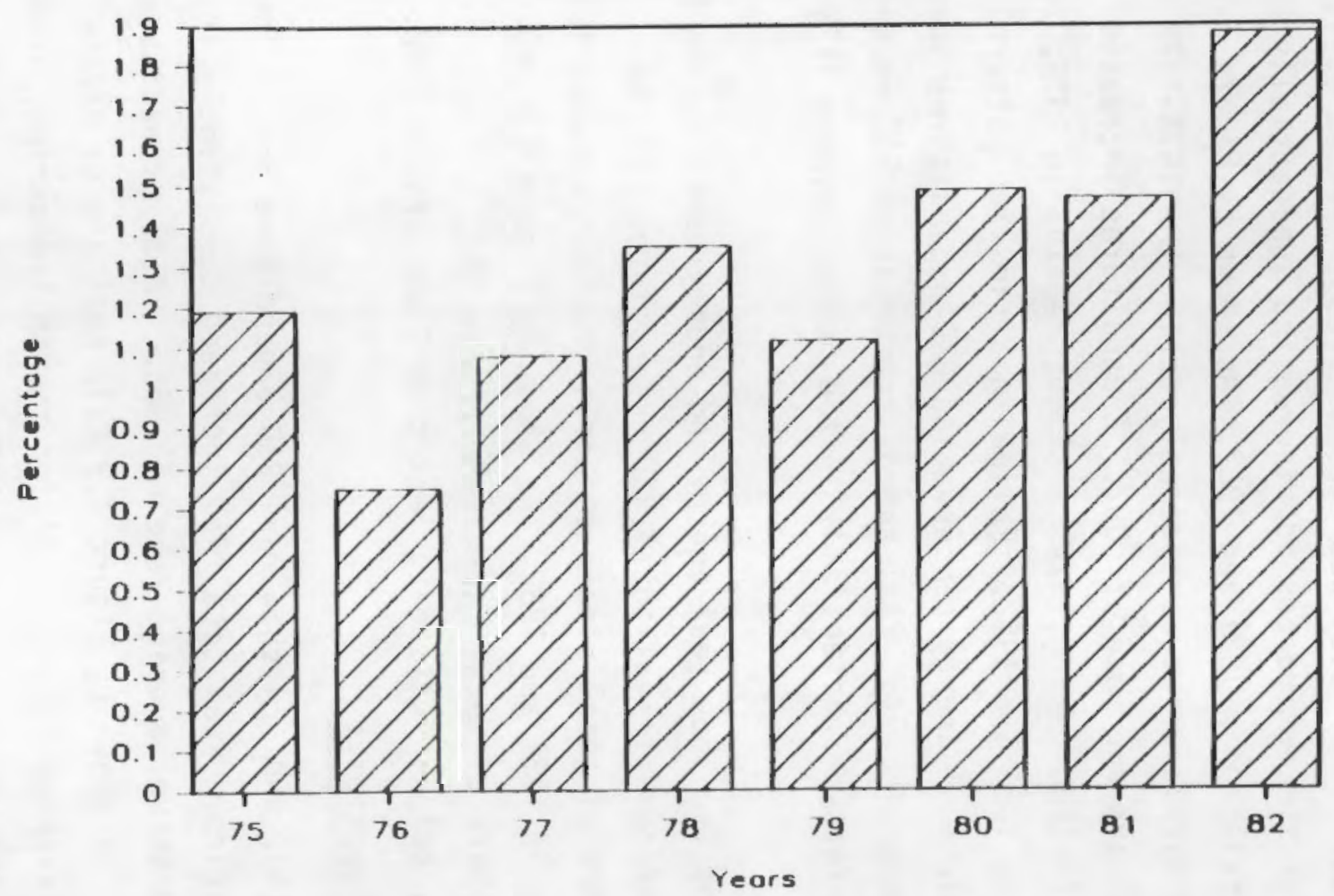

FIGURE 4.7(c). Energy R\&D Expenditures as a Percentage of

Total R\&D Expenditures. Professional and Scientific Instruments Industry.

SOURCE: National Science Foundation. 1984. R\&D in Industry: 1982 Detalled Statistical Tables.

FROM: Pacific Northwest Laboratory. 1985. Recent Trends in Energy Research and Development Expenditures. 


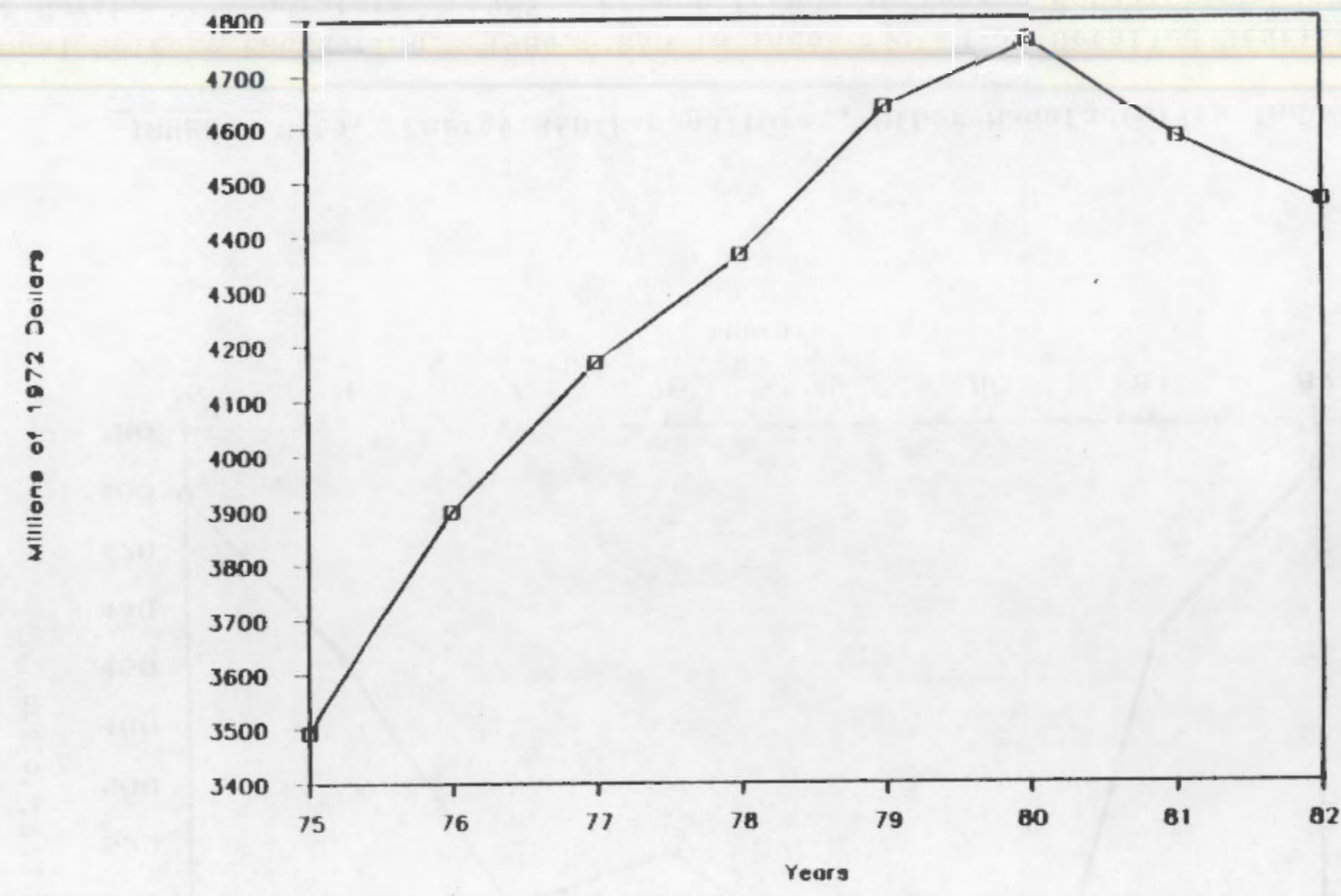

FIGURE 4.8(a). Total R\&D Expenditures, Other Manufacturing Industry.

SOURCE: National Science Foundation. 1984. R\&D in Industry: 1982 Detailed Statistical Tables.

FROM: Pacific Northwest Laboratory. 1985. Recent Trends in Energy Research and Development Expenditures. 




FICURE 4.8(b). Energy R\&D Expenditures, Other Manufacturing Industry.

SOURCE: National Science Foundation. 1984. R\&D in Industry: 1982 Detalled Statistical Tables.

FRoM: Pacif ic Northwest laboratory. 1985. Recent Trends in Energy Research and Development Expenditures. 


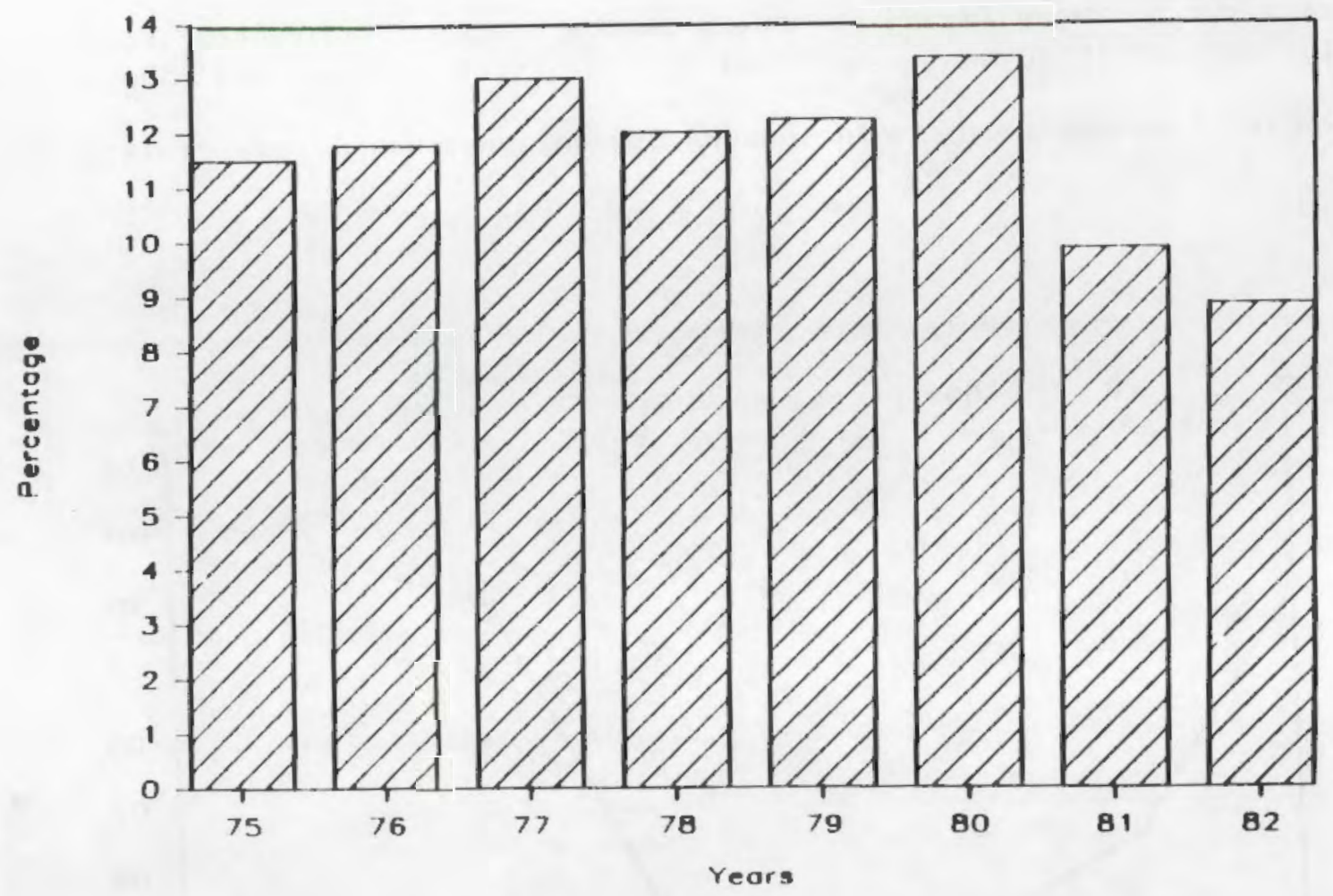

FICURE $4.8(d)$. Energy R\&D Expend1tures as a Percentage of

Total R\&D Expenditures. Other Manufacturing Industry.

SOURCE: National Science Foundation. 1984. R\&D In Industry: 1982 Detalled Statistical Tables.

SOURCE: National Science Foundation. 1984. R8D 1n Industry: 1982 Detailed Stat Development Expenditures.
FROM: Pacific Northwest Laboratory. 1985. Recent Trends in Energy Research and Dever. 


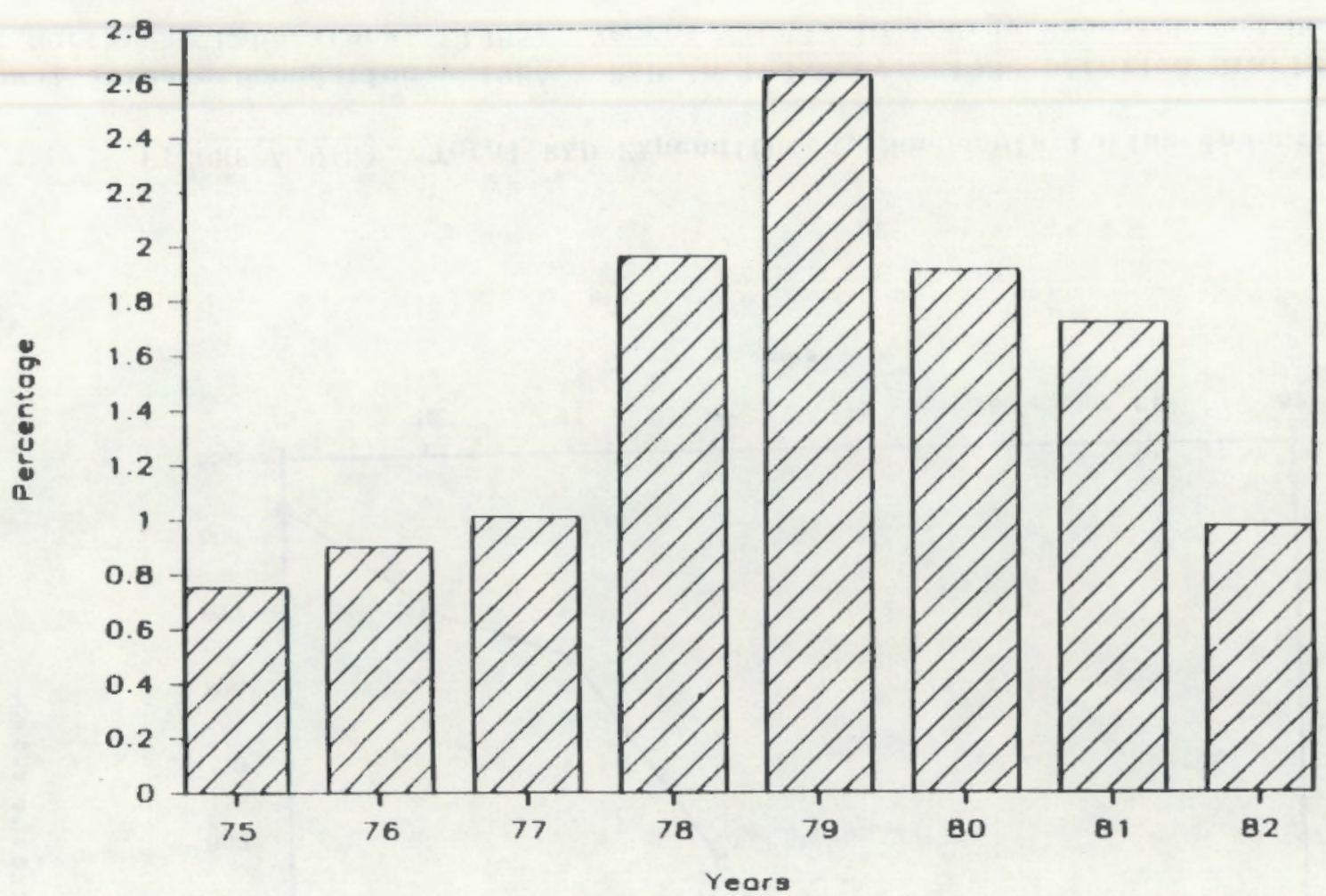

FIGURE 4.8(e). Energy Conservation R\&D Expenditures as a Percentage of Total R\&D Expenditures, other Manufacturing Industry.

SOURCE: National Science Foundation. 1984. R\&D in Industry: 1982 Detalled Statistical Tables. FROM: Pacific Northwest Laboratory. 1985. Recent Trends in Energy Research and Development Expenditures. 


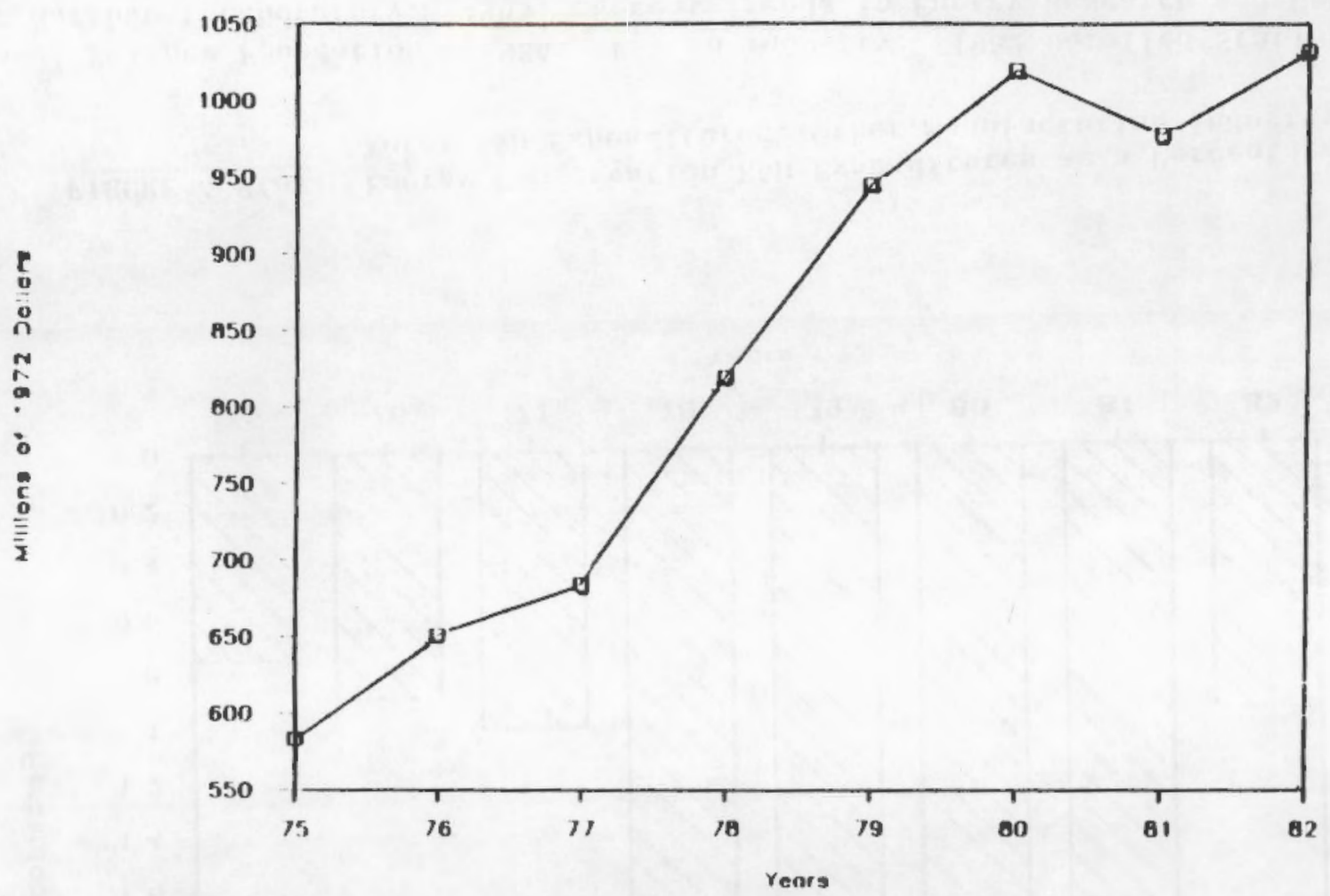

FIGURE 4.9(a). Total R\&D Expendltures, NonManufacturing Industry

SOURCE: National Science Foundation. 1984. R\&D in Industry: 1982 Detalled Statistical Tables. FROM: Pacific Northwest Laboratory. 1985. Recent Trends In Energy Research and Development Expenditures. 


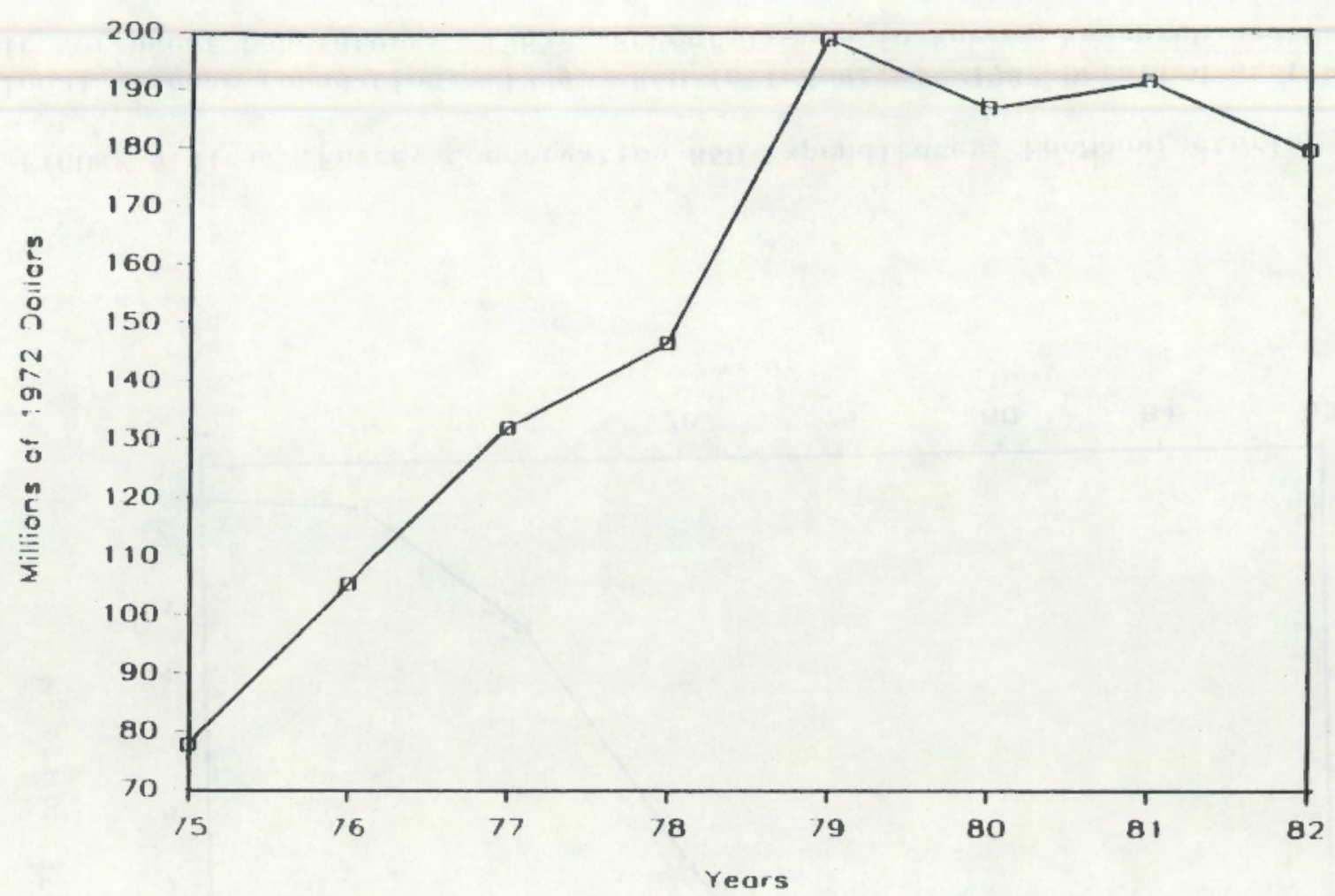

FIGURE 4.9(b). Energy R\&D Expenditures, NonManufacturing Industry

SOURCE: National Science Foundation. 1984. R\&D in Industry: 1982 Detalled Statistical Tables.

FROM: Pacific Northwest Laboratory. 1985. Recent Trends in Energy Research and Development Expenditures. 




FIGURE $4.9(\mathrm{c})$. Energy Conservation RoD Expenditures, NonManufarturing Industry.

SOURCE: National Science Foundation. 1984. R\&D In Industry: 1982 Detailed Statistical Tables. FROM: Pacific Northwest Laboratory. 1985. Recent Trends in Energy Research and Development Expenditures. 
for the entire period, peaking in 1980, before decreasing in 1981 and 1982 .

Figures 4.9 (d) and (e) show real energy and energy conservation R\&D expenditures as a percentage of real total R\&D expenditures for the industry. As shown by Figure 4.9 (d), energy as a percentage of tota 1 varied considerably during the 1975-1982 period, attaining its highest share (approximately 21 percent) in 1979. Energy conservation's share of total, as shown by Figure 4.9 (e), increased in the period between 1975 and 1980, peaking in 1980 at 1.1 percent, before decreasing to less than .8 percent in 1982 .

\subsection{ALL INDUSTRIES}

Figures 4.10 (a), (b), and (c) show real R\&D expenditure trends for all industries combined. Real total R\&D expenditures increased at a near-constant rate of .056 between 1975 and 1982. Real energy R\&D expenditures also increased at an annual average rate of .056 for the entire period, as shown by Figure 4.10 (b). Real energy expenditures increased substantially between 1975 and 1980 before declining in 1981 and 1982 . As shown by Figure 4.10 (c), real energy conservation R\&D expenditures increased at an average annual rate of .111 for the entire period, increasing dramatically in the 1975-1979 period, peaking in 1979, and declining in the period between 1979 and 1982 .

Figures 4.10 (d) and (e) show real energy and energy conservation R\&D expenditures as a percentage of real total R\&D expenditures for all industries. Energy's share of total R\&D increased between 1975 and 1979 , from more than 7 percent to approximately 9.5 percent, before decreasing in 1982 to less than 8 percent. As shown by Figure 4.10 (e), energy conservation's share of total increased substantially during the 1976-1979 period, reaching its peak in 1979 at almost . 9 percent of total, before decreasing by almost the same amounts in the 1980-1982 period. 


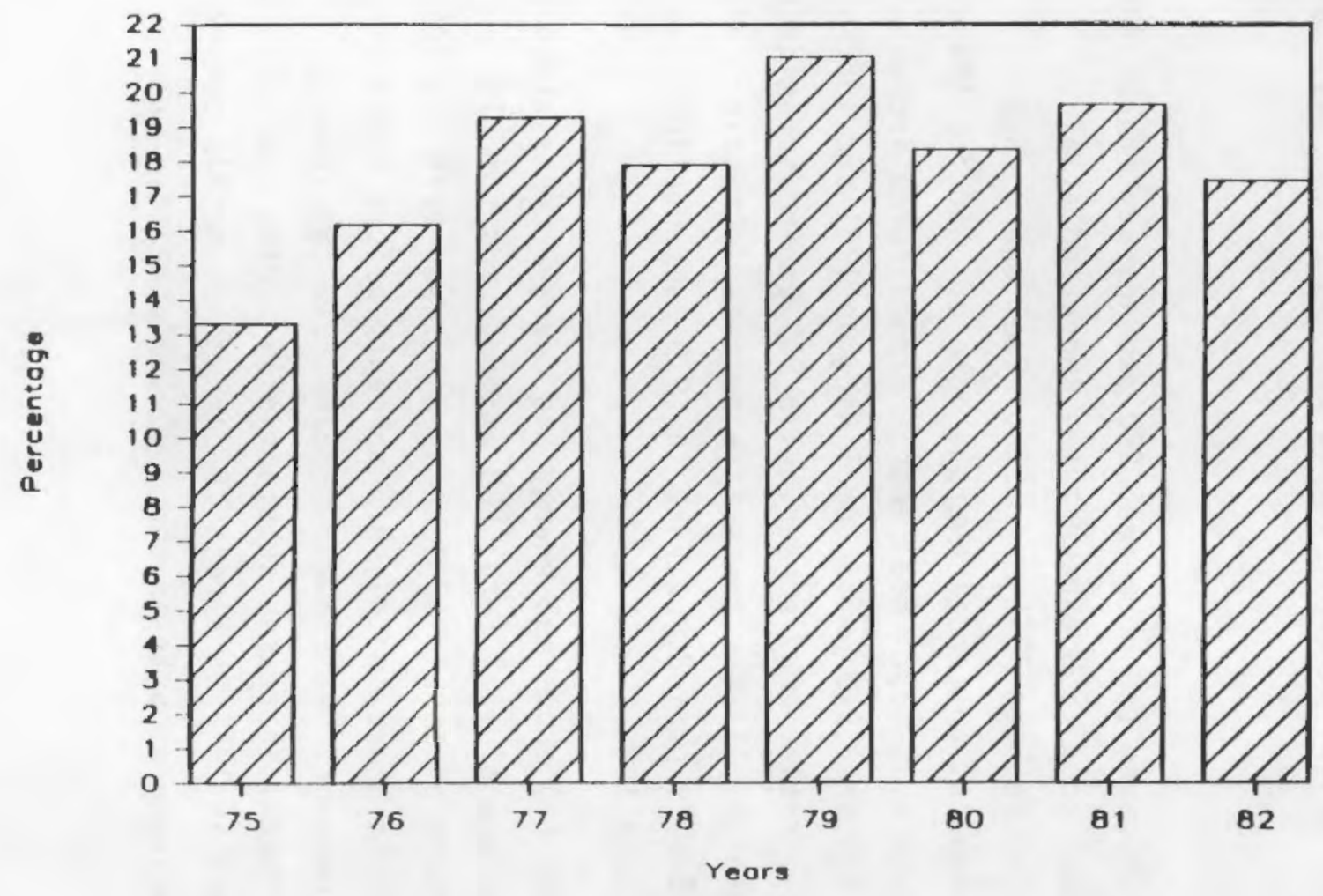

FIGURE $4.9(\mathrm{~d})$. Energy R\&D Expenditures as a Percentage of
Total R\&D Expenditures, NonManufacturing Industry.

SOURCE: National Science Foundation. 1984. R\&D In Industry: 1982 Detalled Statistica1 Tables. FROM: Pacific Northwest Laboratory. 1985. Recent Trends in Energy Research and Development Expenditures. 


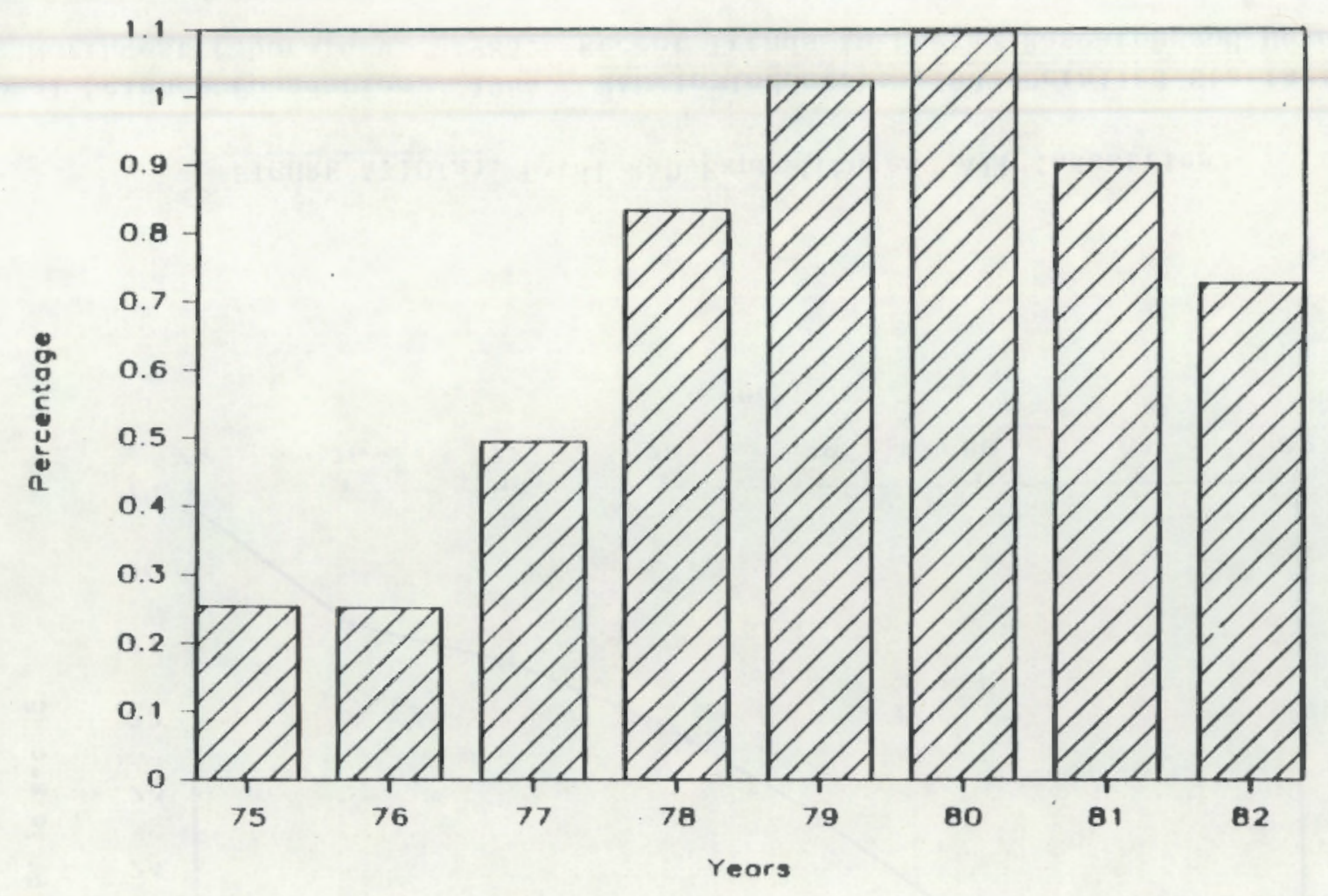

FIGURE 4.9(e). Energy Conservation R\&D Expenditures as a Percentage of Total R\&D Expenditures, NonManufacturing Industry.

SOURCE: National Science Foundation. 1984. R\&D In Industry: 1982 Detalled Statistical Tables. FROM: Pacific Northwest Laboratory. 1985. Recent Trends In Energy Research and Development Expenditures. 


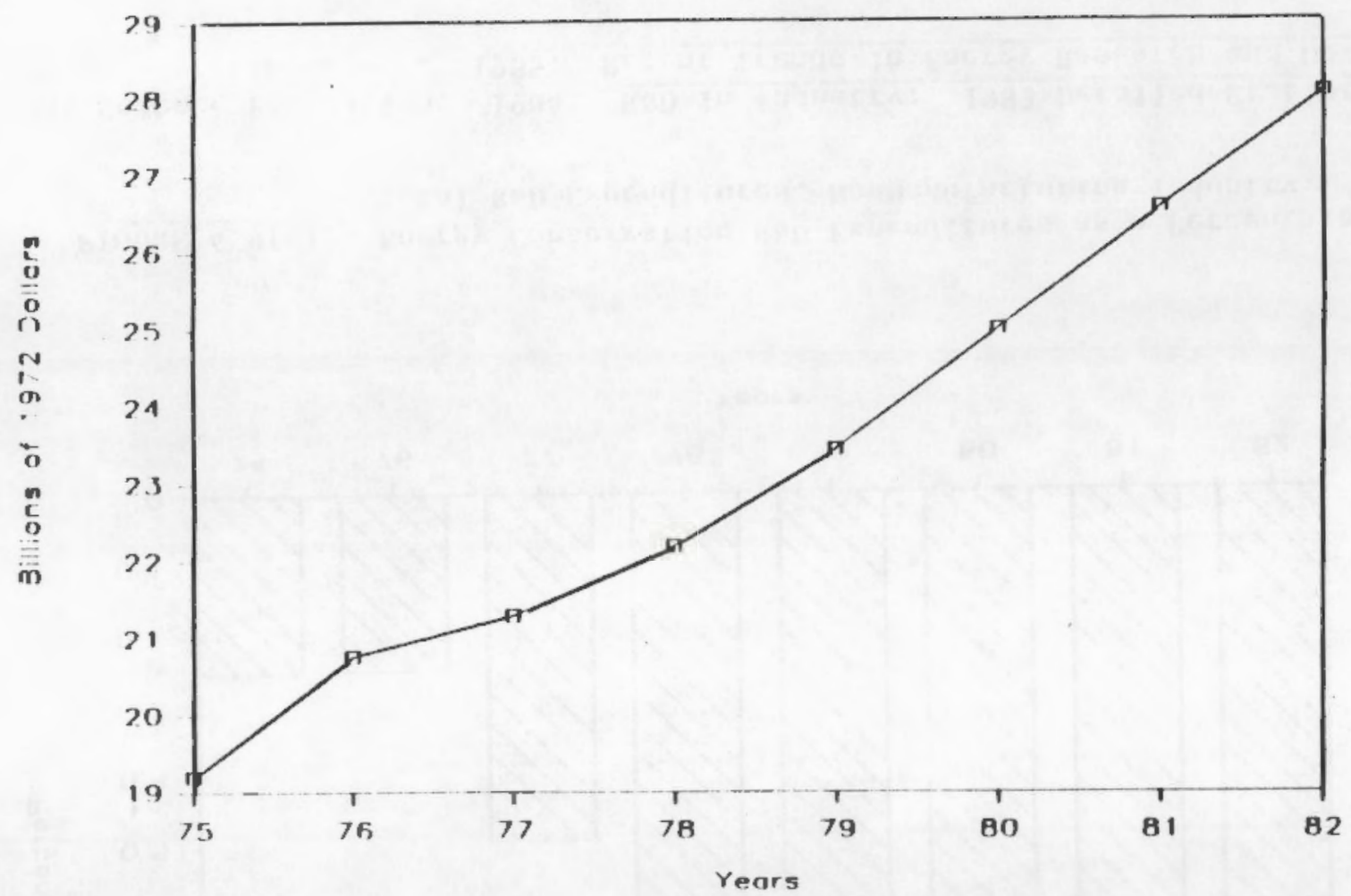

FIGURE 4.10(a). Total R\&D Expenditures, A11 Industries.

SOURCE: National Science Foundation. 1984. R\&D in Industry: 1982 Detalled Statistical Tables. FROM: Pacific Northwest Laboratory. 1985. Recent Trends in Energy Research and Development Expenditures. 


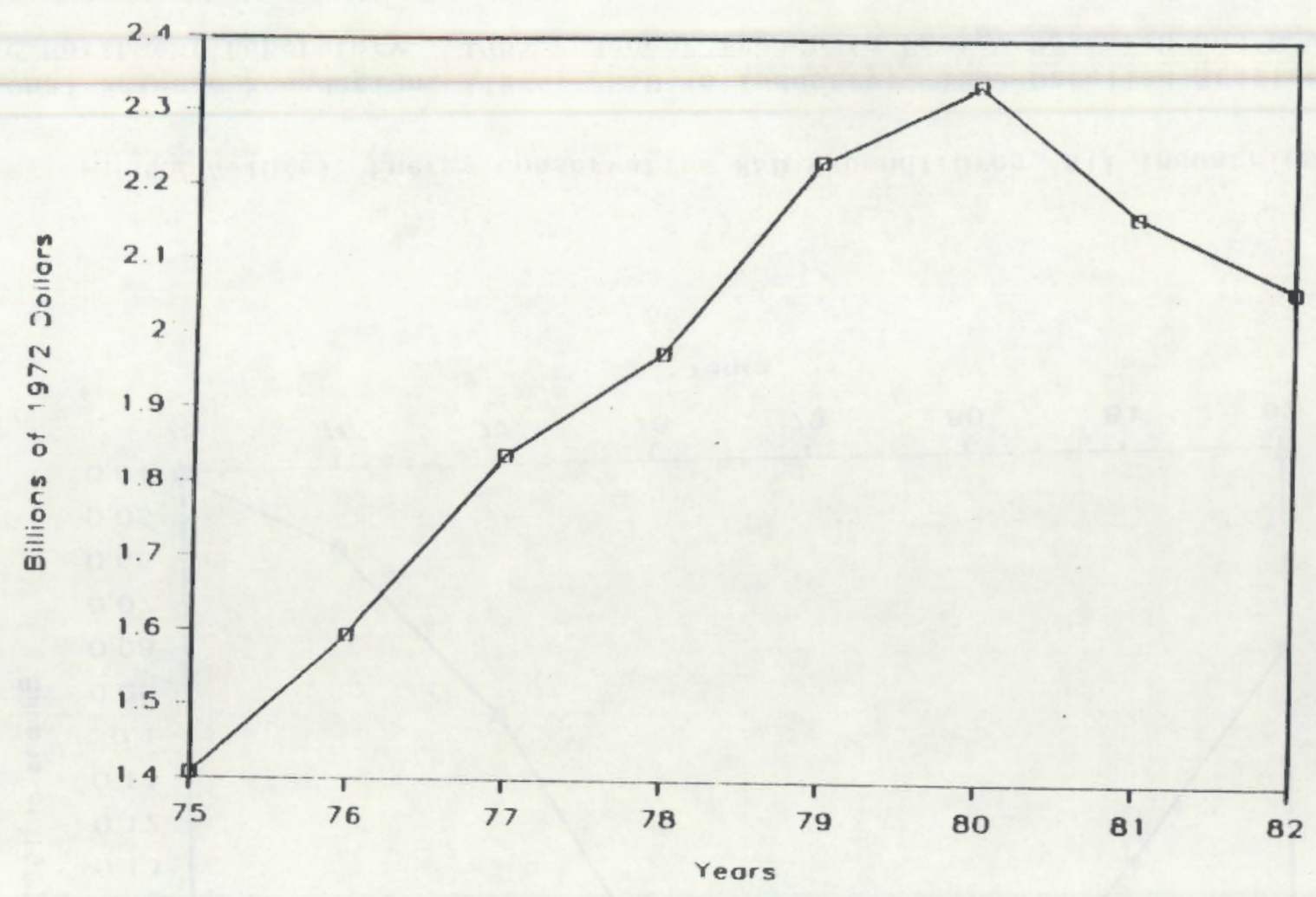

FIGURE 4.10(b). Energy R\&D Expenditures, Al1 Industries.

SOURCE: National Science Foundation. 1984. R\&D in Industry: 1982 Detalled Stat1stical Tables.

FROM: Pacific Northwest Lahoratory. 1985. Recent Trends In Energy Research and Development Expenditures. 


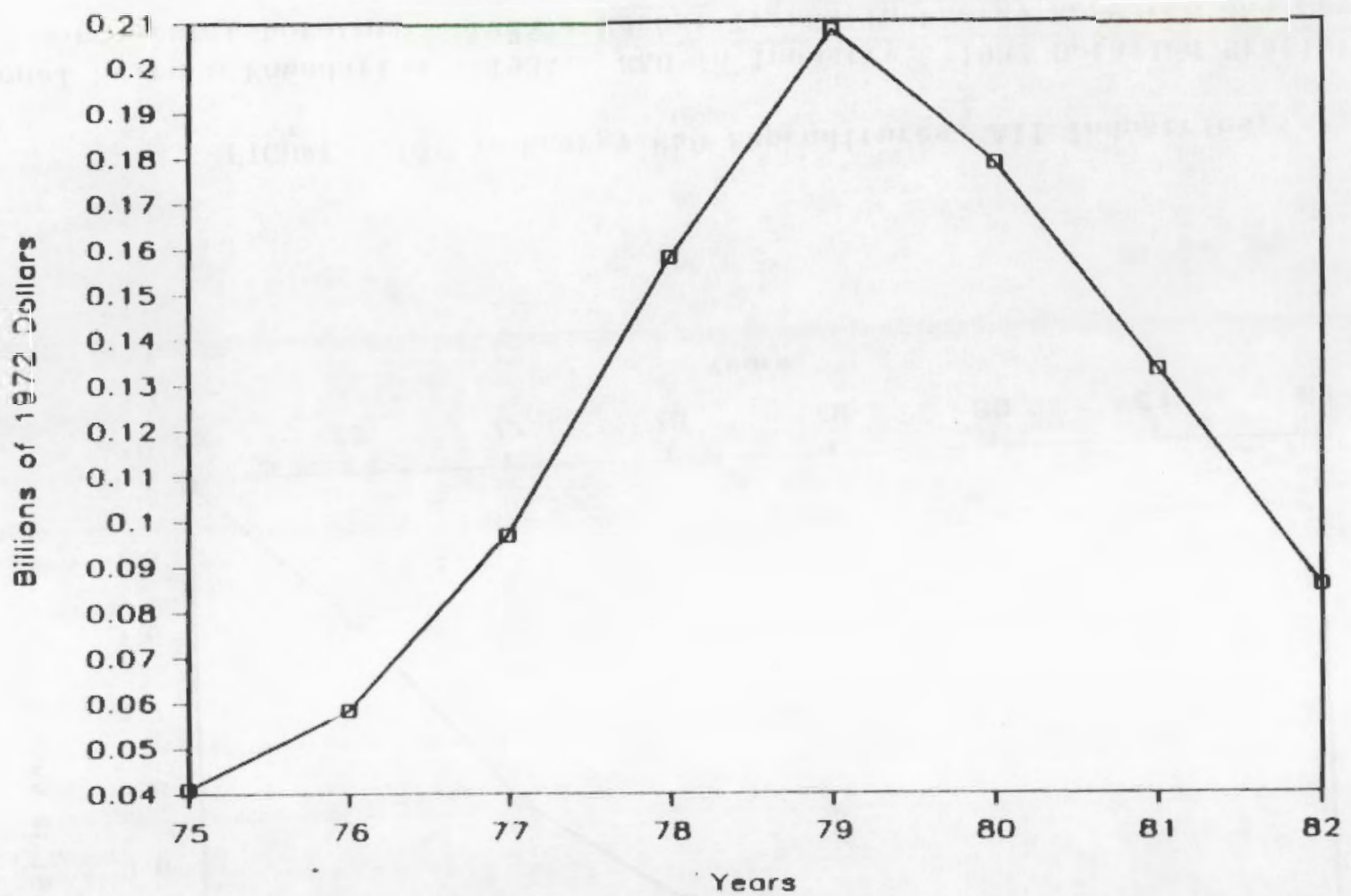

FIGURE 4.10(c). Energy Conservation R\&D Expenditures, All Industries.

SOURCE: National Science Foundation. 1984. R\&D in Industry: 1982 Detalled Statistical Tables. FROM: Pacific Northwest Laboratory. 1985. Recent Trends in Energy Research and Development Expenditures. 


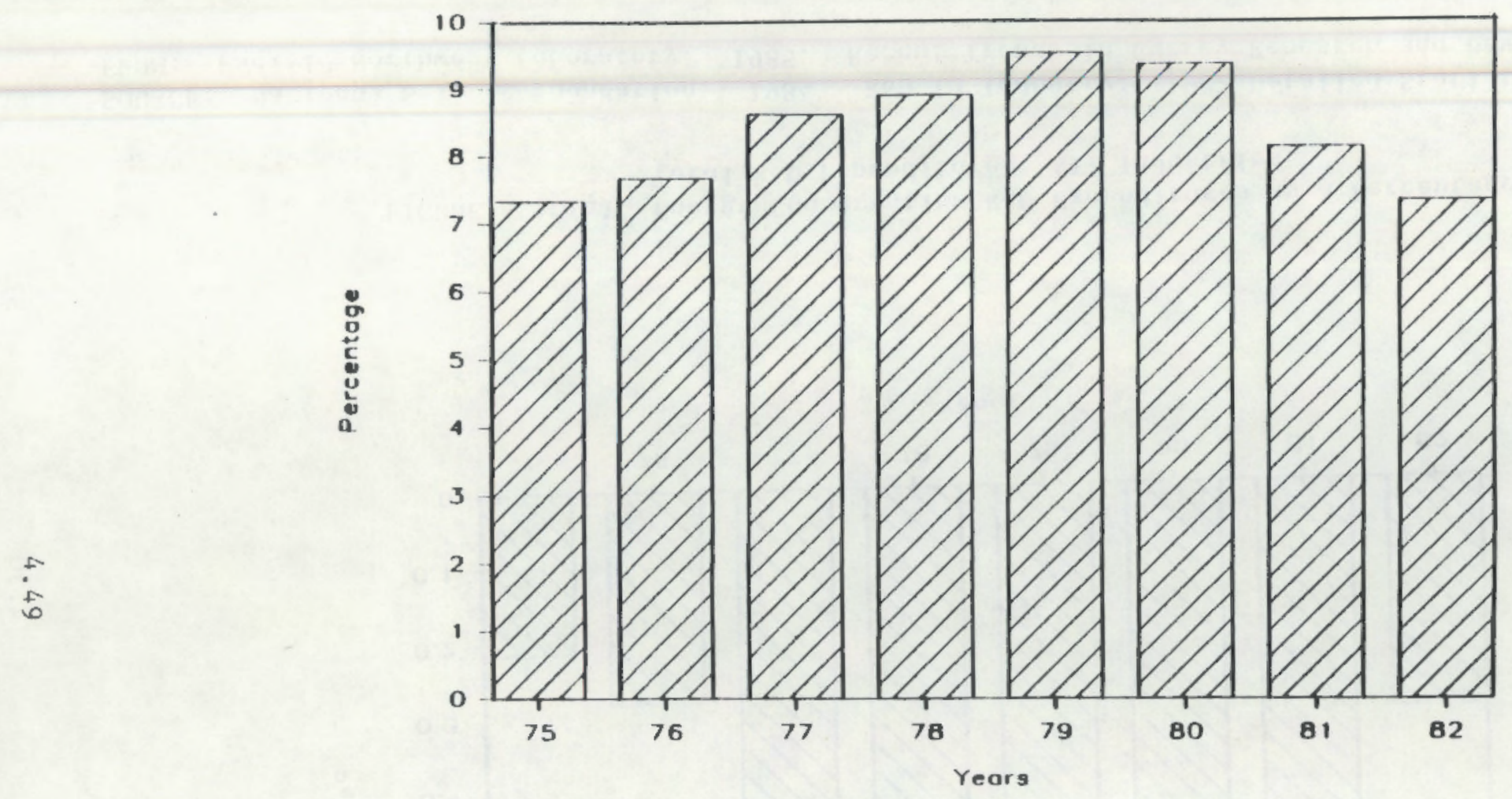

FIGURE $4.10($ d) . Energy RSD Expenditures as a Percentage of Total Expenditures, 111 Industries.

SOURCE: National Science Foundation. 1984. R\&D in Industry: 1982 Detailed Statistical Tables.

FRoM: Pacific Northwest Laboratory. 1985. Recent Trends in Energy Research and Development Expenditures. 


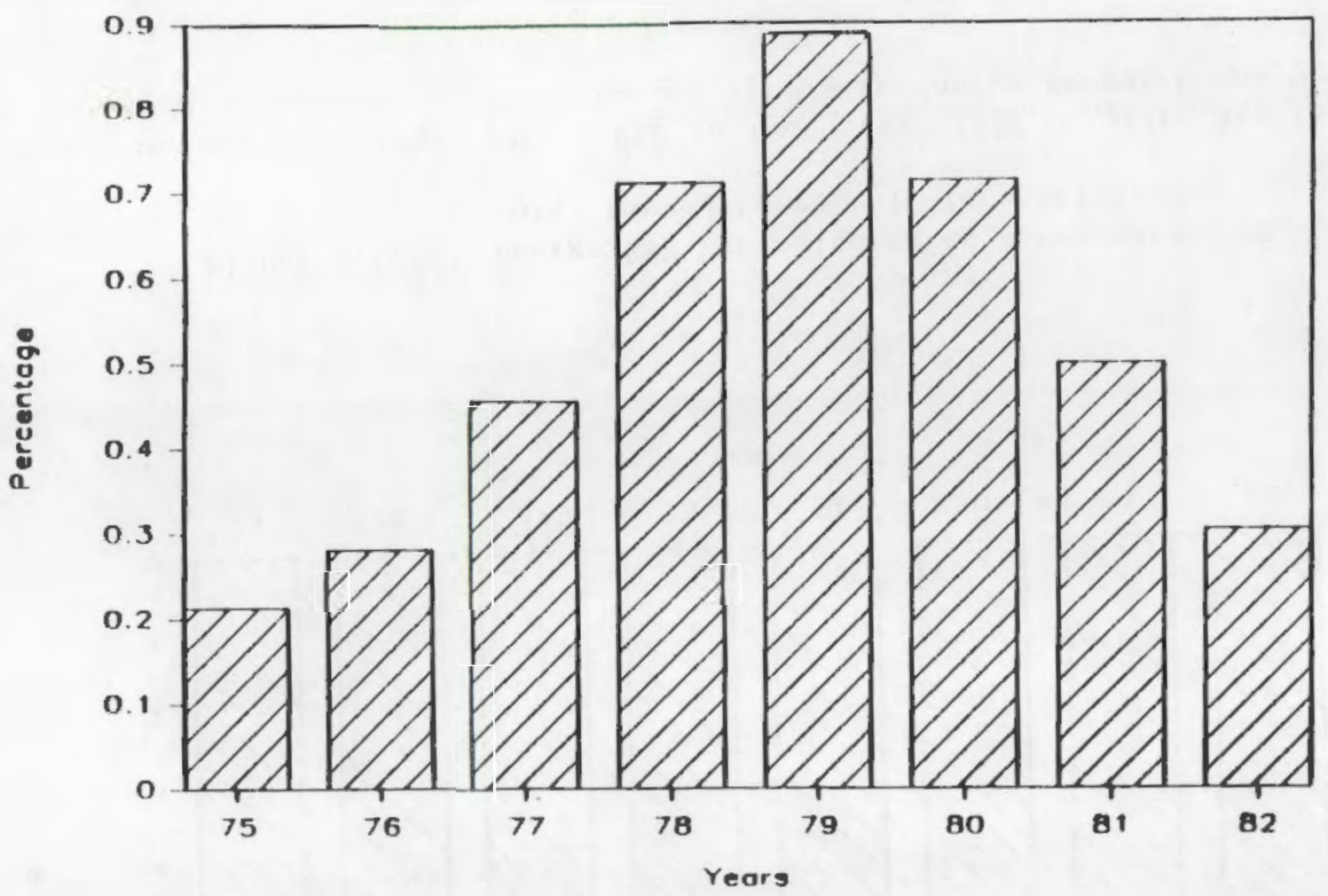

FIGURE 4.10(e). Energy Conservation R\&D Expendttures as a Percentage of Total R\&D Expendtures, All Industries.

SOURCE: National Sclence Foundation. 1984. R\&D in Industry: 1982 Detafled Statistical Tables. FROM: Pacific Northwest Laboratory. 1985. Recent Trends in Energy Research and Development Expenditures.

$$
+\infty
$$




\section{APPENDIX}

DATA FOR GRAPHICAL, NUMERICAL, AND

ECONOMIC ANALYSIS 
FABLE A.1. Research and Development Expendicures, by Industry, Type of RSD, and Year

(Mlllions of Vominal Dollars)

\begin{tabular}{|c|c|c|c|c|c|c|c|c|c|}
\hline & 1975 & 1976 & 1977 & 1978 & 1979 & 1980 & I 981 & $: 982$ \\
\hline \multicolumn{2}{|c|}{$\begin{array}{l}\text { YEARS } \\
\text { TOTAL CHEMICALS }\end{array}$} & 2727 & 3017 & 3202 & 3580 & 4038 & 4636 & 5625 & 6588 \\
\hline \multirow{3}{*}{$\begin{array}{l}\text { ENERGY } \\
\text { ENERGY }\end{array}$} & & 102 & 121 & 148 & 157 & 220 & 257 & 312 & 366 \\
\hline & CONSERVATION & 4 & 6 & 10 & 26 & 2 & 49 & 24 & 24 \\
\hline & PETROLEUM & & & & & & & & \\
\hline \multirow{3}{*}{$\begin{array}{l}\text { TOTAL } \\
\text { ENERGY }\end{array}$} & & 693 & 767 & 918 & 1060 & 1261 & 1552 & 1748 & 1934 \\
\hline & & 405 & 440 & 536 & 648 & 776 & 845 & 1067 & 1183 \\
\hline & PRIMARY YET & & & & & & & & \\
\hline TOTAL & & 443 & 507 & 538 & 560 & 634 & 728 & 878 & 1005 \\
\hline ENERGY & & 27 & 33 & 51 & 49 & 72 & 78 & 80 & 101 \\
\hline \multirow[t]{2}{*}{ ENERGY } & CONSERVATION & 3 & 10 & 18 & 20 & 21 & 25 & 17 & 17 \\
\hline & YACHINERY & & & & & & & & \\
\hline TOTAL & & 3196 & 3487 & 3880 & & 4825 & 5901 & 6818 & 7879 \\
\hline ENERGY & & 23 & 40 & 61 & 80 & 83 & 108 & 127 & 194 \\
\hline \multirow[t]{2}{*}{ ENERGY } & CONSERVATION & 2 & 4 & 12 & 12 & 12 & 9 & 12 & 2 \\
\hline & ELECTRICAL & IENT & & & & & & & \\
\hline TOTAL & & $\$ 105$ & 5636 & 5886 & 6507 & 7824 & 9175 & 10329 & 11925 \\
\hline ENERGY & & 464 & 585 & 650 & 714 & 843 & 917 & 908 & 873 \\
\hline \multirow[t]{2}{*}{ ENERGY } & CONSERVATION & 8 & 8 & 32 & 40 & 49 & 53 & 35 & 30 \\
\hline & AIRCRAFT AN & ILES $^{\mathrm{a}}$ & & & & & & & \\
\hline TOTAL & & 5713 & 6339 & 7033 & 7536 & 8041 & 9198 & 11958 & 14044 \\
\hline \multirow[t]{2}{*}{ ENERGY } & & 134 & 110 & 165 & 283 & 372 & 446 & 412 & 352 \\
\hline & $\begin{array}{l}\text { PROFESSIONA } \\
\text { INSTRUMENTS }\end{array}$ & SCIENT & & & & & & & \\
\hline TOTAL & & 1173 & 1131 & 1571 & 1998 & 2505 & 3029 & 3614 & $\$ 047$ \\
\hline \multirow[t]{2}{*}{ ENERGY } & & 14 & 10 & 17 & 27 & 28 & 45 & 53 & 76 \\
\hline & OTHER MANUT & [NG & & & & & & & \\
\hline TOTAL & & 4402 & 5067 & 5839 & 6551 & 7557 & 8471 & $892 \div$ & 3369 \\
\hline ENERGY & & 507 & 597 & 760 & 787 & 925 & 1133 & 383 & 931 \\
\hline \multirow[t]{2}{*}{ ENERCY } & CONSERVATION & 33 & 46 & 59 & 129 & 199 & 162 & $i 5 ;$ & 32 \\
\hline & NONMANUEACT & & & & & & & & \\
\hline TOTAL & & 735 & 846 & 957 & 1229 & 1539 & 1815 & 1906 & $\therefore 68$ \\
\hline ENERGY & & 98 & 137 & 185 & 220 & 324 & 333 & 374 & 378 \\
\hline \multirow[t]{2}{*}{ ENERGY } & CONSERVATION & 2 & 2 & 5 & 10 & 16 & 20 & 17 & 16 \\
\hline & ALI INDUSTR & & & & & & & & \\
\hline $\begin{array}{l}\text { TOTAL } \\
\text { ENERGT }\end{array}$ & & $\begin{array}{r}24187 \\
1774\end{array}$ & $\begin{array}{r}26997 \\
2023\end{array}$ & $\begin{array}{r}29825 \\
2573\end{array}$ & $\begin{array}{r}33304 \\
2965\end{array}$ & $\begin{array}{r}38226 \\
3643\end{array}$ & $\begin{array}{r}44505 \\
4162\end{array}$ & $\begin{array}{r}51810 \\
4216\end{array}$ & $\begin{array}{r}\$ 3960 \\
\quad+334\end{array}$ \\
\hline BNERGY & CONSERVATION & 52 & 76 & 136 & 237 & 339 & 318 & 260 & $\$ 30$ \\
\hline
\end{tabular}

a Energy Conservation Data Not Avaliable SOURCE: National Science Foundarion 1984. RSD 1n Indugtry: 1982 Detalled StatiscicaI
Tableg.

FROM: Pactfle Northwest Laboratory. 1985. Recenc Trends in Energy Research anc ?evelopment Expendicures. 
TABLE A.2. U.S. Gross National Produce Implicte Price Deflacor, by Year

$(1972=100)$

Year

1975

1976

1977

1978

1979

1980

1981

1982
Deflator

125.79

132.34

140.05

150.42

163.42

178.64

195.51

207.23

SOURCE: Counct1 of Economic Advisers. 1984. Economic Report of the President.

FROM: Pac1f1c Norchwest Laboratory. 1985. Recent Trends in Energy Researza tnd Development Expendicures. 


\section{$\underline{\text { DISTRIBUTION }}$}

No. of

Copies

OFFSITE

20 James Demetrops

U.S. Department of Energy

Office of Industrial Programs

Forrestal Building, Room 56-067

1000 Independence Ave., S.W.

Washington, D.C. 20585

30 DOE Technical Information Center

ONSITE

DOE Richland Operations Office

H.E. Ransom/D.R. Segna

39 Pacific Northwest Laboratory

N.L. Moore (5)

R.J. Moe (20)

J.R. Kee

K.C. Lackey

R.C. Adams (5)

Publishing Coordination (2)

Technical Information (5) 
